International Journal of Korean Humanities and Social Sciences

Vol. $4 / 2018$

DOI: http://dx.doi.org/10.14746/kr.2018.04.01

\title{
KOREAN LANGUAGE EDUCATION IN THE ERA OF GLOBALIZATION \\ - WITH THE FOCUS ON BOOKS AND TEACHING MATERIALS -
}

\author{
Anna BOROWIAK, PhD \\ Choonsil LIM, MA \\ Department of Korean Studies, \\ Institute of Linguistics \\ Adam Mickiewicz University \\ annaboro@amu.edu.pl \\ ggamcs@amu.edu.pl
}

“오늘날 나라의 바탕을 보존하기에 가장 중요한 자기 나라의 말과 글을 이 지경을 만들고 도외시한다면, 나라의 바탕은 날로 쇠퇴할 것이요. 나라의 바탕이 날로 쇠퇴하면, 그 미치는 바 영향은 측량할 수 없이 되어 나라 형세를 회복할 가망이 없을 것이다. 이에 우리 나라의 말과 글을 강구하여 이것을 고치고 바로잡아, 장려하는 것이 오늘의 시급히 해야 할 일이다."

(cf. Ju Si-gyeong. 1908. 'The National Language Classical Phonetics' <국어문전음학> ${ }^{1}$ )

'Hangeul - the key for Our Country (Korea) to become a developed country.'

(Hangeul Foundation ${ }^{2}$ )

\footnotetext{
${ }^{1}$ The official blog of the Ministry of Patriots and Veterans Affairs (MPVA, Kor. 국가보훈처) http://mpva.tistory.com/214 (accessed 31-07-2018).

${ }^{2} \mathrm{Cf}$. http://www.hangul.or.kr/html/index.asp (accessed 14-01-2018).
} 
Abstract: A keen interest in the culture and economic development of the Republic of Korea has resulted in establishing business relations between Korea and various countries all around the world. The Korean War (1950-1953) is said to be the catalyst for Korean Studies, since it has generated a considerable interest in Korean history, language and culture. Yet, when the Korean Language Education (henceforward KLE) is being referred to, usually the years when the boom for "everything that is Korean" started, which could be attributed to the successfully organized Summer Olympics in 1988 and co-organized Asian World Cup in 2002, are being mentioned. This was when the world saw a different side of Korea. However, also thanks to the enormous popularity of Hallyu and the support of the South Korean Government given to initiatives, which among others, popularize the Korean language, the interest in various aspects of Korean culture as well as the language itself, has become higher than ever before. Since the turn of the $21^{\text {st }}$ century, South Korea is perceived as one of the world's leading exporters of culture and tourism, and Hangeul became one of the exported goods.

The aim of this research is to analyze the situation of KLE in the era of globalization, which along with the spread of lingua franca, among them English, is endangering the language variety of the world. In order to do so, several significant dates and initiatives showing how Korean scholars and the Government have influenced and shaped the language policy and thus have contributed to the popularization of the language all around the world will also be referred to. Government sponsored institutions providing Korean language classes, as well as books and other teaching materials, will be discussed and classified. The article will also try to answer the question concerning the future of the KLE.

Key Words: Korean Language Education (KLE), globalization, Korean language institutions, teaching materials

\section{세계화 시대에서의 한국어 교육 현황 -교재와 교육용 자료를 중심으로-}

논문초록: 대한민국의 문화와 경제 발전에 대한 관심은 한국과 세계 각국 간의 통상 관계를 발전시키는 데에 큰 역할을 하였다. 한국 전쟁(1950-1953)은 한국의 역사와 문화 및 한국어에 상당한 관심을 불러일으키는 촉매제가 되었다. 그럼에도 불구하고 한국어 교육을 이를 때 대체로 급성장이 시작된 지난 몇 년간을 언급하는 것은 서울에서 성공적으로 개최된 1988년 하계 올림픽 및 2002년 월드컵 등과 같은 국제스포츠행사들의 결과다. 그 당시에 전 세계는 한국의 새로운 면모를 발견하게 되었다. 한류의 엄청난 
인기와 한국어 교육의 발전을 위한 대한민국 정부의 적극적인 지원 덕분에 다양한 측면의 한국 문화와 한국어에 대한 관심이 그 어느 때보다 높아졌다. 한국은 21 세기 초반부터 세계적으로 문화 관광의 주요 수출국으로 인식되어 왔으며, 한글은 그 수출품 중 하나가 되었다.

본 연구의 목적은 영어 등과 같은 링구아 프랑크라의 확산과 세계 언어의 다양성을 위협하고 있는 세계화 시대에서의 한국어 교육 현황을 분석하는 데에 있다. 본 주제를 광범위하게 논의하기 위해 먼저 주요한 사업계획과 일정을 통해서 한국 학자들이 정부와 더불어 언어 정책에 어떤 영향을 미쳤는지, 그 정책을 어떻게 수립해 왔는지, 이를 통해 어떻게 한국어를 전세계적으로 확산시키는 데에 이바지하였는가를 알아보고자 한다. 또한 한국 정부로부터 지원을 받아 한국어 교육을 제공하는 교육기관을 살펴볼 것이다. 뿐만 아니라 교재 및 기타 교육용 자료의 특성을 논의한 다음 그 분류를 제시할 것이다. 이 연구는 향후 전세계 한국어 교육의 미래에 관한 질문에 답을 찾으려 한다.

주제어: 한국어 교육, 세계화, 한국어 교육 기관, 교육용 자료

\section{DYDAKTYKA JĘZYKA KOREAŃSKIEGO W ERZE GLOBALIZACJI - ZE SZCZEGÓLNYM UWZGLĘDNIENIEM PODRĘCZNIKÓW ORAZ POMOCY DYDAKTYCZNYCH}

Streszczenie: Żywe zainteresowanie kulturą oraz rozwojem gospodarczym Korei Południowej doprowadziło do nawiązania stosunków handlowych między Koreą a różnymi krajami na całym świecie. Wojna koreańska (19501953) uważana jest za katalizator studiów koreanistycznych, ponieważ wzbudziła duże zainteresowanie koreańską historią, językiem i kulturą. Niemniej jednak, mówiąc o dydaktyce języka koreańskiego, ma się zwykle na myśli ostatnie lata, kiedy to nastał boom na wszystko, co koreańskie. Jest to, oczywiście, wynik pomyślnie zorganizowanych bądź współorganizowanych w Seulu międzynarodowych wydarzeń sportowych, takich jak m.in. Letnie Igrzyska Olimpijskie (1988) czy Mistrzostwa Świata w Piłce Nożnej (2002). To właśnie wtedy świat ujrzał inne oblicze Korei. Jednakże również dzięki ogromnej popularności Hallyu oraz wsparciu Rządu Korei Południowej dla inicjatyw służących m.in. popularyzacji języka koreańskiego zainteresowanie różnymi aspektami koreańskiej kultury, jak również samym językiem koreańskim stało się większe niż kiedykolwiek wcześniej. Od początku XXI wieku Korea Południowa jest postrzegana jako jeden ze światowych liderów, promujących swoją kulturę i turystykę, a alfabet koreański - Hangeul stał się jednym z jej towarów eksportowych.

Celem niniejszego artykułu jest dokonanie analizy sytuacji dydaktyki języka koreańskiego w erze globalizacji, która wraz 
z rozprzestrzenianiem się m.in. języka angielskiego jako lingua franca zagraża różnorodności językowej świata. Aby w jak najpełniejszy sposób przedstawić badane zagadnienie jako pierwsze zostaną przytoczone daty najważniejszych wydarzeń, bez których nie można byłoby mówić o współczesnej dydaktyce języka koreańskiego, oraz inicjatywy pokazujące, w jaki sposób koreańscy naukowcy oraz Rząd Republiki Korei kształtowali i nadal kształtują politykę językową, a tym samym przyczyniają się do popularyzacji języka koreańskiego na całym świecie. Zostaną tu również przywołane różne instytucje oświatowe, oferujące zajęcia z języka koreańskiego, a działające dzięki rządowemu finansowaniu. Ponadto, zostaną tu omówione i sklasyfikowane podręczniki do nauki języka koreańskiego oraz inne pomoce dydaktyczne. Artykuł spróbuje udzielić odpowiedzi na pytanie dotyczące przyszłości dydaktyki języka koreańskiego na świecie.

Słowa klucze: dydaktyka języka koreańskiego, globalizacja, instytucje oferujące zajęcia $\mathrm{z}$ języka koreańskiego, materiały dydaktyczne

\section{Introductory Remarks}

The term globalization is usually defined as a process of interaction and integration among the people, companies and governments of different nations, a process driven by international trade and investment and aided by IT. This process has effects on the environment, culture, political systems, economic development, prosperity, and human physical wellbeing in societies around the world. ${ }^{3}$ Consequently, the adopted policies such as free-market economic systems and technological developments not only have spurred increases in international trade and investment, but also contributed to the growth of migration rates as well.

Even though there is no confusion as to what the globalization is, there are some discrepancies concerning its beginnings. The process itself is said to be nothing new, since for thousands of years people and later, corporations have been trading with one another regardless of the geographical distances, e.g. through the famed Silk Road during the Middle Ages. Nonetheless, some

\footnotetext{
${ }^{3}$ The Neil D. Levin Graduate Institute of International Relations and Commerce at the State University of New York (cf. http://www.globalization101.org/what-isglobalization/, accessed 14-06-2016).
} 
modern economic historians dispute the argument of Adam Smith one of the early economists, that the discovery of the Americas, by Christopher Columbus in 1492 accelerated this process. Kevin O'Rourke and Jeffrey Williamson argue in a 2002 paper that the globalization only really began in the $19^{\text {th }}$ century, when a sudden drop in transport costs allowed the prices of commodities in Europe and Asia to converge (cf. The Economist, 23-10-2013).

The globalization itself though deeply controversial, has its proponents and opponents. Despite all the pros and cons, its effect on many areas of human life, among them education, is simply undeniable. It reflects a new form of cultural imperialism, as Chinnammai (2005: 1) points out, and produces a shift in society from industrialization towards information-based society, as it shapes children - the future citizens of the world into 'global citizens', intelligent people with broad range of skills and knowledge, people who know how to apply the knowledge and be more competitive. Globalization and technological advancements along with changes in labor market not only confirm the internationalization of education, but also indicate their close connection. It is understandable that e.g. international companies look for qualified employees not only as far as the fluency in a foreign language is concerned, but also with deep understanding of the target culture, and thus business environment, thanks to which also the company can successfully compete in the global market. From this point of view education itself can be perceived as a kind of commodity.

Nevertheless, in this context it is impossible not to refer to the sociolinguistic consequences of globalization and the theory of language and the communicative community as its fundamental concept, proposed by Professor Ludwik Zabrocki (1963). Professor Zabrocki argues that the communicative community is formed when there are at least two people, between which there is a need for communication and when this need is realized, and perceives language as the most important element unambiguously indicating a given community. The external and concrete proof for the existence of these communities is the existence of a concrete means of communication, meaning a language (cf. p. 12). Yet, it is also worthy to mention that people constituting a particular communicative community, do not have to communicate in one language only. Although the language community is a communicative community, it is defined as group of people using relatively unified means of communication meaning the common language. Every 
communicative community aims to create a single means of communication, which would support the whole community. In other words, as Professor Bańczerowski (2014: 160) puts it, 'each and every communicative community wants to become a language community'.

As far as the above-mentioned processes are concerned, Professor Zabrocki (1963: 9-33) emphasizes, that the integration of societies driven primarily by the economic reasons results in formation of bigger communicative communities, where either the synthesis of languages or the extinction of a language used by the community perceived from the social point of view, as worse or subordinate one, takes place. This means that the extinction of languages and dialects is the result of every integration of communicative communities when the synthesis of communicative communities perceived as equal does not take place. This means that from the social viewpoint to smaller or bigger extent, there will always be an evaluation of languages - one of them will win over the other one (cf. p. 9-17). Consequently, the number of languages decreases proportionally to the decrease in the number of communicative communities and the linguistic integration follows over time, despite the fact that it is not the battle between the languages but between the societies. All of that helps to create the global communicative community, which would cover the whole world. This however endangers other already existing communicative and language communities. This situation can be perceived as linguistic or language imperialism, which over time results in the situation, where the superior communicative community eliminates the subordinate one. ${ }^{4}$ Professor Zabrocki also points out a different aspect of so-called communicative integration, namely the fact that language communities are more than communicative communities having one language, since every nation identifies itself through the language, which reflects their spiritual and material identity (cf. p. 19). Nonetheless, the number of world-wide communicative communities is constantly growing, they also become more solid. This results also in multilingualism of native communicative communities.

One of the most easily noticeable aspects of globalization in the educational context is the advantage to learn a foreign language,

\footnotetext{
4 The globalization shows that English is among the preferred or prioritized languages, yet in the future it may be Asian-English.
} 
even 'the rare' one, from its native speaker without the necessity to go abroad. Another one is the opportunity to take part in international training courses or exchange programs for both academic staff and students, who can go abroad, study for one or two terms or even receive their $\mathrm{BA}, \mathrm{MA}$ or $\mathrm{PhD}$ degrees, and after returning back home have them recognized. Not to mention the possibility to co-host international conferences and symposia, to carry out researches or to co-organize guest lectures and consultations as well as to cooperate in the field of scholarly publications, the sharing of library digitalized resources etc. Of course, signing academic agreements between the universities, as well as the ability to take advantage of the scholarship system offered by foreign countries, would not be possible if it was not for the previous agreements on the government level, which as a cooperation is a clear sign of internationalization and globalization. ${ }^{5}$

Nevertheless, the negative effects of internationalization (and globalization) on education can also be observed. Despite the fact that we live in the Internet Era and ubiquitous technological progress, where the question concerning the hampered accessibility to the Internet and online resources caused by the case of not having a computer might appear to be rather surrealistic, yet it concerns some parts of the global population. In other words, lack of resources to provide and implement technological advancements disable less affluent families, schools, communities or even whole countries from competing in the already-mentioned global labor market. Another question concerns the whole system of education, in which the didactics of a foreign language, culture or history is prioritized over the didactics of the mother tongue and national culture or history of a student. It happens when more school hours are spent on teaching a foreign language or languages, than of the native one or when classes are devoted only to the history and customs of other countries without prior explanation of the uniqueness of the local ones. This,

\footnotetext{
${ }^{5}$ In June 1993 Poland and South Korea have signed the agreement on scientific and technical cooperation, thanks to which signing the agreements between Polish and Korean universities became possible, and thus Polish students can go to Korea for language course or regular studies. Nevertheless, from the economic point of view, masters and doctoral courses became more popular when the Government Scholarship Program (GSP) was introduced.
} 
without a shadow of a doubt, would lead to weakening or even losing the national identity, which in some cases can also be noticed. ${ }^{6}$

The aim of this research is to analyze the situation of Korean Language Education (henceforward KLE) in widely understood aspect of globalization, with the focus on various didactic materials published for Korean language learners. In order to present the situation in question in a broader context, a few very important events, without which we would not be able to talk about the situation whatsoever, along with initiatives taken up by the Korean Government and various organizations in order to improve it, will also be discussed here. The article will also try to answer the question of what the future holds for the didactics of Korean. This research, however, does not present every single Korean language textbook that was published within the past few decades nor every institution offering Korean language courses around the world, for the priority is given to institutions, which were established as a result of a conscious policy of the Korean Government in order to preserve and popularize Korean language and culture world-widely. As a consequence, the situation concerning institutional aspect will focus only on institutes, centers and school of Korean origin (often sponsored by the Korean Government), instead of universities all around the world, which offer Korean language courses as electives or regular studies.

\section{Globalization in the context of Korean Language Education}

Since the dawn of time, stronger and bigger countries not only tended to expand their territories but they would also impose their languages. Examples of the above-mentioned language imperialism are in fact numerous around the world. In this context, there is a very good reason to fear that globalization threatens the languages of smaller and thus economically weaker countries, also in the context of already

\footnotetext{
${ }^{6}$ At this point it is also worth mentioning the situation of the universities all around the world. Chinnammi (2005: 3-4) notices that the universities are being forced to compete in the global capitalist market and have to engage in entrepreneurial activity in order to sustain themselves in an increasingly 'uncertain world', while the governments have been particularly concerned that universities serve the national interests in the global marketplace.
} 
mentioned global communicative community. There are some exceptions though and Korea is one of them.

During the Korean War (1950-1953) and right after the armistice was signed, nobody would have imagined that one of the poorest countries in the world would experience the 'Miracle on the Han River' in becoming one of the world's leading economy powers and that in just a few decades, the interest in Korean language and culture would grow as much as it has.

Language is said to be one of the determinants of cultural identity. The fact how proud the Korean People are of their alphabet and language can be easily confirmed by the conscious and well thought out policy of the Korean Government, observable in legislations and through various initiatives taken up by government and non-government organizations, foundations and Korean Culture Centers, which are to strengthen the national competitiveness and to preserve, standardize, as well as promote and expand the usage of Korean language and culture all around the world through various courses and events, often co-organized with Korean Embassies. Furthermore, the aim of those organizations is also to e.g. support the education for overseas Koreans, to reinforce the usage of the Korean language through administrating Test of Proficiency in Korean (TOPIK) or to exchange students under various programs. That is the reason why so many non-Korean students have become interested in Korean culture and desire to study Korean - some simply as a hobby but others for professional purposes, dreaming about the possibility of a future career in South Korea - either in diplomacy or business.

Nonetheless, it would be impossible to discuss the present situation of KLE if it was not for numerous very important facts. Enumerating all of them would be impossible considering the scope of this article, that is why only some of them will be presented below.

\subsection{Some important dates}

1446 - the publication of the document titled Hunminjeongeum (Kor. 훈민정음) meaning 'The Proper Sounds for the Education of the People', after which the native script of Korea was named, 
1908 - the foundation of the Korean Language Society (Kor. 국어연구학회), the aim of which was to preserve the Korean language during a time of Japanization (in 1933 it introduced the Proposal for Unified Hangeul Orthography; Kor. 한글 맞춤법 통일안) and in 1949 it was renamed as the Korean Language Society (Kor. 한글학회),

1926 - the first celebration of the Korean Alphabet Day - today known as the Hangeul Day (Kor. 한글날), in order to commemorate the invention and the proclamation of Korean alphabet, ${ }^{7}$

1927 - the Korean Language Society (Kor. 한글학회) publishes the first issue of academic journal - Hangeul (Kor. 한글),

1962 - the establishment of Student Advisory Center of Seoul National University (Kor. 재일동포 모국 수학기관) to support education for Korean-Japanese (the beginnings of the National Institute for the International Education - NIIED, Kor. 국제교육진흥원), reestablished as the Education Center for Overseas Koreans (Kor. 재외국민교육원) in 1977 ,

1985 - the establishment of the International Association for Korean Language Education (Kor. 국제한국어교육협회) ${ }^{8}$, which in 2001 started workshops for Overseas Korean educators,

1991 - the establishment of the National Institute of Korean Language (NIKL, Kor. 국립국어원), the Korea Foundation (KF, Kor. 한국국제교류재단) and the Association of Korean Language Education Research (Kor. 국어교육학회),

1992 - the reorganization of the above-mentioned NIIED, which in 2008 changed into the National Institute for International Education (NIIE, Kor. 국립국제교육원) ${ }^{9}$,

1995 - the establishment of the Hangeul Foundation (Kor. 한글재단), which supports students, teachers and researchers of Korean language and literature,

1997 - UNESCO inscribed Hangeul on its list of Memory of the World Heritage,

\footnotetext{
${ }^{7}$ The first celebration was however called Gagyanal (Gagya Day, Kor. 가갸날), since Hangeul was at that time referred to as Gayageul (Kor. 가갸글). In South Korea it is celebrated on October $9^{\text {th }}$, while in North Korea it is called Joseongeullal (조선글날) and is celebrated on January $15^{\text {th }}$.

8 http://www.iakle.com/contents/bbs/bbs_content.html?bbs_cls_cd=002001002 (accessed 01-10-2016).

9 http://www.niied.go.kr/eng/contents.do?contentsNo=73\&menuNo=326 (accessed 01-10-2016).
} 
After the Word Cup in 2002 and with the help of the so-called Korean Wave (Kor. 한류, Hallyu) the number of people, who became interested in Korean culture and language started to grow all around the world. That is why it became necessary to introduce an official examination to test the language proficiency in order to keep up with rising demand. As a consequence, in

1997 - TOPIK examination (the Test of Proficiency in Korean for nonKorean residents) was conducted for the first time ${ }^{10}$.

Graph 1 . The overall number of applicants and those who have successfully passed the TOPIK ${ }^{11}$

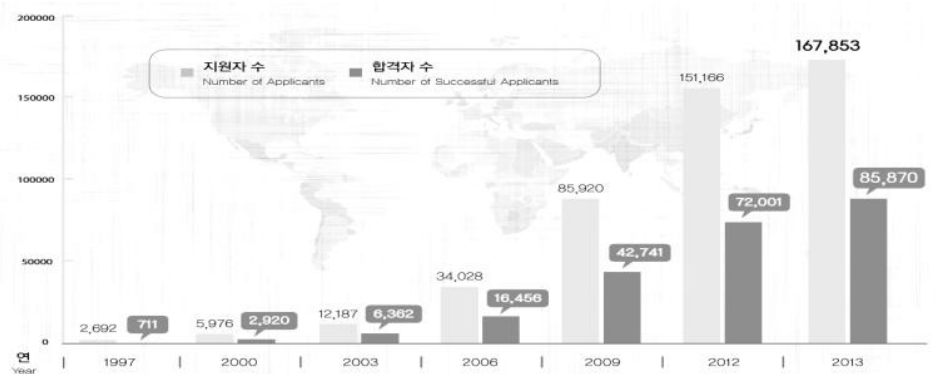

Source: The NIKL『2014 숫자로 살펴보는 우리말』 ${ }^{12}$

${ }^{10}$ The NIIED is the $3^{\text {rd }}$ organization to supervise the examination. Before that it was administered by the Korea Research Foundation (KRF, Kor. 한국학술진흥재단; years 1997-1998) and the Korea Institute for Curriculum and Evaluation (KICE, Kor. 한국교육과정평가원; years 1999-2010).

${ }^{11}$ As Graph 1. shows, despite the fact that in 1997 only 2692 students took the exam, the number of TOPIK examinees has been increasing sharply and thus so was the number of Korean language institutes. As one can see from the data provided by the NIKL within 16-years-time the number of applicants has risen more than 63 times. Even though the successful applicants' ratio in 2013 was only $51.15 \%$, yet in comparison to $26.21 \%$ 1997, it was almost twice as high. Although the Graph 1 . does not present it, the number of applicants in 2015 was 174,881 and one year later it was higher about 75000 . The growing number of examinees all around the world is probably the reason why the Korean MOE provides the statistics concerning the number of all applicants as well as those who actually have passed the exam only till 2013.

${ }^{12} \mathrm{http} / / /$ korean.go.kr/front/etcData/etcDataView.do;front=F5A4AF3FDA920FB24661 16A4461C2DCA?mn_id=46\&etc_seq=429\&pageIndex=1 (accessed 13-01-2018). 
Even though the first TOPIK exam was only conducted in South Korea, over time it was and still is conducted in many countries all around the world - in 2013 it took place in 61 countries (in 194 places around the world). From the $46^{\text {th }}$ edition (October $15^{\text {th }} 2016$ ) it is also possible to take it in Poland (at the Institute of Middle and Far East Studies of the Jagiellonian University). ${ }^{13}$ It is also worthy to mention that before the year of 2000, the TOPIK exam was taken mainly by foreign students, who wished to enter Korean universities, nevertheless after 2000 the reasons behind taking up the exam have diversified. With the introduction of the Employment Permit System in 2005 - passing the test by foreign immigrant workers became obligatory. Those, who are applying for working visas, those who want to get a visa as a marriage immigrant etc. need to pass this exam, as well (marriage immigrants have to pass at least $1^{\text {st }}$ level). The TOPIK score is also essential for foreign nationals who plan to enter a Korean university since most of the universities require at least the $3^{\text {rd }}$ level.

2001 - the establishment of the International Korean Language Foundation (IKLF, Kor. 한국어세계화재단), by the Ministry of Culture Sports and Tourism (MCST, Kor. 문화체육관광부), its role is to promote Korean language and Korean language globalization among foreigners,

- the foundation of the Educational Foundation for Koreans Abroad (EFKA, Kor. 재외동포교육진흥재단), focused on the education of overseas Koreans,

2005 - the enactment of the 'Framework Act on the National Language', which was the Basic Law of Korean National Language (Kor. 국어기본법), ${ }^{14}$

\footnotetext{
13 'The Korea Times' quoting the words of Education Ministry wrote in April 2016, that the record number- 72,295 of foreigners took the $46^{\text {th }}$ edition of the TOPIK test that month

(cf. http://www.koreatimes.co.kr/www/news/nation/2016/04/181_202734.html, accessed 17-07-2016).

${ }^{14}$ It defined the direction of the KLE to Koreans and the basic policy concerning Korean language teaching to foreigners. As a consequence, the MCST affiliated organizations implemented the policies prepared in order to standardize the educational process. Among the policies mentioned here were those concerning the spreading of the Korean language overseas. Consequently, through the Korean Language Society (Kor. 한글학회) and the NIKL, the above-mentioned policies could be implemented in earnest. The law also introduced the system of examinations for Korean language teachers. Till November 2014 the number of qualified teachers reached 16.484 people 
- the establishment of the King Sejong Institute Foundation (KSIF, Kor. 세종학당재단), ${ }^{15}$

- the introduction of the Employment Permit System - Test of Proficiency in Korean (EPS-TOPIK, 한국어능력시험), targeted at foreign immigrant workers,

2009 - the establishment of the Presidential Council on National Branding (PCNB, Kor. 국가 브랜드 위원회 $)^{16}$

2013 - opening of the National Hangeul Museum (Kor. 국립한글박물관) in Seoul,

- the Korean Alphabet Day became the national holiday in South Korea.

It is also worthy to mention the existence of the digital museum devoted entirely to Hangeul (Digital Hangeul Museum, Kor. 디지털 한글 박물관) ${ }^{17}$ or King Sejong the Great Memorial Hall

https://elaw.klri.re.kr/eng_mobile/viewer.do?hseq=28092\&type=sogan \&key=8 and http://www.law.go.kr/lsInfoP.do?1siSeq=136820\&efYd=20130323\#0000, accessed 12-12-2017).

${ }^{15} \mathrm{KSIF}$ is a central public institution launched by the South Korean Government supporting the King Sejong Institutes (KSI, Kor. 세종학당). Is regarded as the most representative overseas educational institution of the Korean language and culture. It was established on the basis of the Article 9, Section 2 of the 'Framework Act on the National Language' in order to coordinate the management of the government's propagation project of the Korean language and Korean culture all around the world. 김중섭 (2013) analyzes what effects do KSIs have on Korea, and suggests how it can grow side by side Korean companies in order to succeed on the global stage. He suggests, among others, receiving continuous and systematic support from the \{Korean\} Government, establishing Korean language research centers, strengthening the internal organization, evaluating and managing each individual institute.

${ }^{16}$ Its objective is to promote Korea's global image - as economically advanced nation - and to right misconceptions about Korea as well as to raise the respect for the country, its culture and values, its products and people. The goal is to raise Korea's brand from near the bottom of the member states of the OECD to the middle (13 out of 31 countries) by 2013. (http://17koreabrand.pa.go.kr/gokr/en/cms/selectKbrdCmsPageTbl.do?cd=0117\&m1= $1 \& \mathrm{~m} 2=2$, accessed 23-11-2017). It is worthy to mention that under the tagline "Korea, A Loving Embrace" there are ten main activities being promoted by the PCNB: (1) Shaping the Future with Korea, (2) Campus World: Global Korea Scholarship, Campus Asia, (3) Korean Supporters, (4) Global Korean Network, (5) Promoting Korean language and Taekwondo, (6) Global Citizenship, (7) Advanced Technology \& Design Korea, (8) Rainbow Korea, (9) Friendly Digital Korea, (10) Korea Brand Index (https://southasiacommunication.wordpress.com/report-5-nation-brandingsouth-korea/, accessed 14-10-2017).

${ }^{17}$ Although Hangeul and Korean culture are the most important heritage, which 
(Kor. 세종대왕기념관).

Korean pride of Hangeul and its willingness to preserve it as well as to popularize it all around the world reveals itself also in very simple things such as Hangeul fashion shows, Hangeulthemed tourist attractions or monuments, paintings etc., which also decorate subway stations and streets. Tourists eagerly buy clothes and souvenirs with Hangeul ornaments. The promotion became one of the ways, in which Korea has started to advertise the country itself along with its culture, and thus contributed to the increase the international awareness about the country. We can say that Hangeul and Korean language teaching have become a kind of export good, which is to get as many foreigners interested in Korea and Korean and thus visit the country simply for sightseeing, studies or business, as possible.

Rapid technological progress along with awareness and well thought out policy of the Korean Government has resulted not only in marveling the world with the beauty of Korean traditional culture, but also in raising the awareness of its values among the nations all around the world. Easily accessible Korean movies and dramas, TV shows, books and the Internet have played the leading role here. When we ask foreigners why do they study Korean, they usually say that they are fans of K-POP or love Korean dramas (this means that the decision to take up Korean classes is the result of Korean popculture expansion all around the world) or they simply dream about finding employment in Korean companies (which is the result of expansion of Korean companies overseas).

\subsection{A brief history of Korean Language Education}

The growing importance of KLE all around the world, especially for the last two decades is undeniable. Nevertheless, the didactics

identifies Korean People, there have been many barriers to make Hangeul known domestically and overseas because most of Hangeul data was separately retained in many museums, research institutes and by individuals. Thus, urgent requirements are arising to make a system that integrates and centralizes Hangeul and its data. To meet these current requirements - to digitalize and preserve Korean script and its cultural properties for a long time and provide professional discussion on its merit for worldwide public information, the Digital Hangeul Museum was established as a five-year project of 2001 to 2005 (cf. http://english.visitkorea.or.kr/enu/AKR/AK_ENG_2_1_4.jsp, accessed 12-02-2017). 
of Korean Language (henceforward KL) itself started much earlier and so did the development of teaching materials. Several scholars, who divide the above-mentioned development into few periods or stages, discuss the history of KLE. 조항록 (2003) distinguishes three of them, while others such as 고경민 (2012) twice as many, as the below Table 1 . shows.

The stages in question are based on various criteria, among them - the stages of economic growth and development of South Korea (cf. 백봉자 2001) or the changing approach to KL teaching reflected in the structure of units of both textbooks and other teaching materials (cf. 이지영 2003). ${ }^{18}$ For 고경민 (2012), who provides a full-scale research on the history of books on KL and comments on the controversial points taken up in previous researches, both internal and external factors should be considered while distinguishing the periods of KLE. For him, the books became the criterion for the division of the periods in question. He noticed that since textbooks reflect the character of particular language institution, the educational object, the target group of learners, the teacher, teaching method and teaching policy, all of them could serve as the above-mentioned criteria.

As far as the history of the KLE is concerned 조항록 (2003) notices that the $1^{\text {st }}$ stage would differ, according to the place it actually took place - meaning whether it was in Korea or abroad. Consequently, 1987 - would be the beginning for KLE abroad (the introduction of KL course at Saint Petersburg State University), and 1959 in Korea (the opening of Korean Language Institute by Yonsei University).

Table 1. Periods of the KLE

\begin{tabular}{|c|c|l|}
\hline Author & Stage/ Period & \multicolumn{1}{|c|}{ Characteristic features } \\
\hline \multirow{3}{*}{ 백봉자 } & $\begin{array}{c}\text { the } 1^{\text {st }} \text { stage } \\
(1959-1975)\end{array}$ & $\begin{array}{l}\text { - there is no discussion about KLE before } \\
1959,\end{array}$ \\
\cline { 2 - 3 } $12001:$ & $\begin{array}{c}\text { the quickening stage/ } \\
\text { period } \\
(1976-1988)\end{array}$ & $\begin{array}{l}\text { - noticeable acceleration of the pace, } \\
\text { in which books and other teaching } \\
\text { materials for foreigners were developed, }\end{array}$ \\
\hline
\end{tabular}

18 오대환 (2009: 6-9) however, notices that there is no correlation between the stages based on the internal situation of Korea and the history of KLE. He points out that before the worldwide debate about the didactics of KL was enlivened every country providing KLE already had its own KLE history. 


\begin{tabular}{|c|c|c|}
\hline & $\begin{array}{l}\text { the } 3^{\text {rd }} \text { stage } \\
(1989-2000)\end{array}$ & $\begin{array}{l}\text { - started after the } 1988 \text { Olympics, } \\
\text { as a consequence of the socio-economic } \\
\text { development, the number of KL learners } \\
\text { rapidly increased and the reasons behind } \\
\text { choosing to study Korean diversified, } \\
\text { - the methods used in books came the way } \\
\text { from audio-lingual approach } \\
\text { to the communicative one, }\end{array}$ \\
\hline & $\begin{array}{l}\text { the } 4^{\text {th }} \text { stage } \\
\text { (after 2001) }\end{array}$ & $\begin{array}{l}\text { - projects concerning KLE became } \\
\text { countywide thanks to the involvement } \\
\text { of organizations such as e.g. the Korea } \\
\text { Foundation, }{ }^{19}\end{array}$ \\
\hline \multirow{3}{*}{$\begin{array}{l}\text { 조항록 } \\
\text { (2003: } \\
\text { 225- } \\
233)\end{array}$} & $\begin{array}{l}\text { the quickening stage/ } \\
\text { period } \\
(1897-\text { mid 1980s })\end{array}$ & $\begin{array}{l}\text { - the establishment of the first institutions } \\
\text { providing KLE (it started with } \\
\text { the establishment of few universities } \\
\text { and educational institutions offering KL } \\
\text { classes at the end of the } 1970 \text { s), } \\
\text { - books were compiled and revised, yet not } \\
\text { many new books were developed, }\end{array}$ \\
\hline & $\begin{array}{l}\text { the spring period } \\
\text { (mid 1980s } \\
\text { - mid 1990s) }\end{array}$ & $\begin{array}{l}\text { - the number of students as well as KL } \\
\text { institutions grew thanks to the further } \\
\text { economic development, } \\
\text { - various teaching materials were } \\
\text { developed, }\end{array}$ \\
\hline & $\begin{array}{l}\text { the period of steady } \\
\text { growth } \\
\text { (after mid 1990s) }\end{array}$ & $\begin{array}{l}\text { - progressive and stable growth } \\
\text { in the number of KL learners, } \\
\text { - KL institutions got interested } \\
\text { in developing new books and teaching } \\
\text { materials, new editions of already } \\
\text { published books were also released, }\end{array}$ \\
\hline $\begin{array}{l}\text { 이지 영 } \\
(2003: \\
371- \\
381 \\
2004 \text { : }\end{array}$ & $\begin{array}{l}\text { the } 1^{\text {st }} \text { stage } \\
\text { (the Age } \\
\text { of Enlightenment } \\
-1958)^{20}\end{array}$ & $\begin{array}{l}\text { - the changes in textbooks, educational } \\
\text { institutions and in the target groups } \\
\text { of learners (since } 1870 \text { in Korea and } \\
\text { abroad grammar and conversation books } \\
\text { written mainly by foreign missionaries } \\
\text { were started to be published), }\end{array}$ \\
\hline
\end{tabular}

${ }^{19}$ As a consequence, the environment for mature debate on KLE was created. Teaching materials were based on the communicative approach and problem solving, which meant departing from the audio-lingual approach. The division on stages shows, that there was no debate about KLE before 1959 and that is was based on the stages of economic development of Korea.

20 이지영 (2003) in contrast to 백봉자 (2001) and 조항록 (2003) perceives the Age of Enlightenment as the beginning of modern education. Nonetheless, despite considering the internal motivation for KLE, there is no reference concerning the changes in the establishment of the $1^{\text {st }}$ stage period. 


\begin{tabular}{|c|c|c|}
\hline \multirow[t]{4}{*}{ 150) } & & $\begin{array}{l}\text { - institutions offering KLE were } \\
\text { established in Korea and abroad, } \\
\text { - books for overseas Koreans were also } \\
\text { developed, }\end{array}$ \\
\hline & $\begin{array}{l}\text { the quickening period } \\
\text { (1959-1986) }\end{array}$ & $\begin{array}{l}\text { - the establishment of KL Institute at } \\
\text { Yonsei University, Myeongdowon (Kor. } \\
\text { 명도원) and others, which started to } \\
\text { develop materials for KLE purposes, }\end{array}$ \\
\hline & $\begin{array}{l}\text { the } 3^{\text {rd }} \text { stage } \\
(1986-1997)\end{array}$ & $\begin{array}{l}\text { - growing interest in the KL } \\
\text { as a consequence of hosting the } 1988 \\
\text { Summer Olympics in South Korea, } \\
\text { accompanied with the establishment } \\
\text { of institutes providing } \\
\text { and the development of books used in } \\
\text { those institutes, }\end{array}$ \\
\hline & $\begin{array}{l}\text { the } 4^{\text {th }} \text { stage } \\
\text { 1998-present) }\end{array}$ & $\begin{array}{l}\text { - further rise in the number of institutions } \\
\text { providing KLE and active development } \\
\text { of books by those institutions, } \\
\text { - books became focused on learners, } \\
\text { as a consequence books according } \\
\text { to the learners mother tongue were } \\
\text { developed, textbooks focused on one or all } \\
\text { language functions were also developed, } \\
\text { - technological development enabled } \\
\text { to create multimedia books as well, }\end{array}$ \\
\hline \multirow{3}{*}{$\begin{array}{l}\text { 고경민 } \\
\text { (2012: } \\
21-25)\end{array}$} & $\begin{array}{l}\text { the period focused } \\
\text { on translation } \\
\text { and interpretation } \\
\text { (before 1870) }\end{array}$ & $\begin{array}{l}\text { - the major objective of KLE was } \\
\text { the translation/ interpretation, } \\
\text { - the books were limited to vocabulary } \\
\text { and conversation books, }\end{array}$ \\
\hline & $\begin{array}{l}\text { the modern } \\
\text { quickening period } \\
(1870-1910)\end{array}$ & $\begin{array}{l}\text { - KL books (starting from the book } \\
\text { by a foreign scholar - John Ross) were } \\
\text { compiled, they drifted away from books } \\
\text { traditionally focused on vocabulary } \\
\text { and went in the direction of the descriptive } \\
\text { grammar, focused on parts of speeches } \\
\text { or presenting brief dialogues, compiled } \\
\text { in conversation books, }\end{array}$ \\
\hline & $\begin{array}{l}\text { the period } \\
\text { of quantitative } \\
\text { expansion } \\
(1910-1945)\end{array}$ & $\begin{array}{l}\text { - it is the period of Japanese occupation, } \\
\text { during which published books were } \\
\text { generally grammar books without any } \\
\text { exercises whatsoever, } \\
\text { - instead of focusing on the content, bigger } \\
\text { focus was placed on the volumes } \\
\text { of published books, }\end{array}$ \\
\hline
\end{tabular}




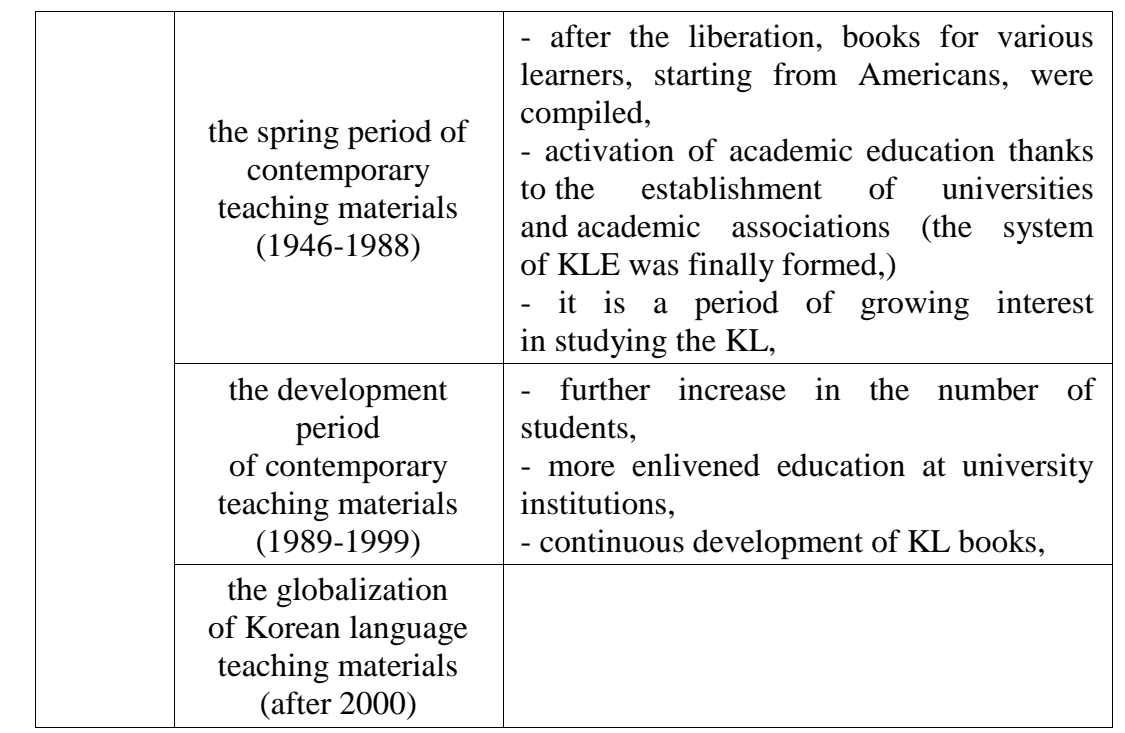

Source: (cf. 고경민 2012)

Since the main goal of this research is to analyze KL books and teaching materials published after 2000, the overall analysis of the history of KL books will be based on the division proposed by 고경민(2012). In paragraph 2.4 teaching methods and the types of major books along with their features will be briefly described, according to those 6 stages.

\subsection{Korean Language Institutions ${ }^{21}$}

As far as the KLE is concerned it can be understood as both - teaching Korean to foreigners and to the native Koreans. As far as the first one is concerned, it can be understood as either teaching Korean as a $2^{\text {nd }}$ language or as a foreign one. ${ }^{22}$ This research focuses mainly

${ }^{21}$ The term 'Korean Language Institutions' refers to the institutions sponsored by the South Korean Government providing KL and culture classes, as an element of a conscious policy to popularize them among foreigners and overseas Koreans. This means that other numerous institutions such as universities, language centers etc., which operate abroad, despite having the same goal, will not be listed in the below Table 2 .

${ }^{22}$ It is worthy to mention, that the differences concerning the didactics of a language whether it is the learner's mother tongue or not, as well as those referring 
on teaching $\mathrm{KL}$ as a foreign language, nonetheless while referring to the teaching materials, those for overseas Koreans and North Korean refugees will also be referred to.

For the last two decades the number of students interested in studying the KL and applicants to take TOPIK exam has been growing with every year. The rise in the number of academic institutions, public institutions and language centers, to teach Korean and culture is, without a doubt, a response to the growing demand. Some of them have been offering foreigners a complete range of courses taught in Korean or English. The number of those institutions is growing with every year, and this trend will continue in the future. Consequently, the number of programs on Korean studies will for sure continue to grow as well. The growing need for more focused programs can be observed through the activity of e.g. the International Association for Korean Language Education (IAKLE, Kor. 국제한국어교육학회, established in 1985) and the European Association for Korean Language Education (EAKLE, Kor. 유럽한국어교육자협희, established in 2007), which regularly organize international conferences devoted to various aspects concerning KLE. ${ }^{23}$

Usually while referring to the popularity of Korean the National Institute of the Korean Language (NIKL, Kor. 국립국어원) and the International Korean Language Foundation (IKLF, Kor. 한국어세계화재단) are mentioned, since they help to establish individual language courses at educational institutions abroad. It is worthy to mention, that in 2006 'Standard Korean Language Education Curriculum Model Development Project' was introduced in 10 countries, among them Mongolia, Thailand, the Philippines, Malaysia, Singapore, China, Taiwan, Sri Lanka and Vietnam. From 2010 with the focus on King Sejong Institutes (henceforward KSIs) a project concerning popularization

to the didactics of the $2^{\text {nd }}$ language and a foreign one were noticed in the $1960 \mathrm{~s}$ by a Polish scholar Professor Ludwik Zabrocki in "Językoznawcze Podstawy Metodyki Nauczania Języków Obcych”(1966: 51-60).

${ }^{23}$ Every year the subject of conferences is different - the $26^{\text {th }}$ IAKLE conference held in Seoul in 2016 was organized under the theme of 'Differentiated Korean Language Education for Language Purposes and Learners', the $27^{\text {th }}$ one was titled 'Practice of Mutual Cultural Viewpoint in Korean Classrooms', while the last one was focused on 'The New Perspective on Korean Language Teaching Materials in the Age of Technological Revolution'. It is worthy to mention that despite the fact that both conferences are international ones, they are generally conducted in Korean. 
and standardization of the teaching process and the curriculum was adopted, and that the number of KSIs all around the world is growing with every year. ${ }^{24}$

Choe Sang-Hun in the NY Times - Asia Pacific wrote an article titled 'South Korea's Latest Export: Its Alphabet' (12-102009), which confirms the huge expansion of Hangeul. It is also worthy to notice a conscious promotion of Hangeul and its popularization all around the world. Two types of strategies are being used by the South Korean Government in order to do so, namely the short-term and the long-term one. Within the first one the Government encourages to use the name Sejonghakdang (Kor. 세종학당) and the standard textbooks, while the second one is to run an integrated language institute. The King Sejong Institute Foundation (KSIF, Kor. 세종학당재단) systematically supports the institutes around the world.

Table 2. Korean Language Institutions all around the world and the number of students

\begin{tabular}{|c|c|c|}
\hline Educational Institution & $\begin{array}{c}\text { Number of } \\
\text { Institutions }\end{array}$ & $\begin{array}{c}\text { Number of } \\
\text { Students }\end{array}$ \\
\hline King Sejong Institute (Kor. 세종학당) & $130^{25}$ & 37,177 \\
\hline Hangeul School (Kor. 한글학교) & $1918^{26}$ & 106,397 \\
\hline Korean School (Kor. 한국학교) & $31^{27}$ & 12,322 \\
\hline $\begin{array}{c}\text { Korean Education Center } \\
\text { (Kor. 한국교육원) }\end{array}$ & $\begin{array}{c}39 \\
(17 \text { countries) }\end{array}$ & 30,000 \\
\hline $\begin{array}{c}\text { Korean Programs in Overseas Colleges } \\
\text { (Kor. 국외 대학 한국어 강좌) }\end{array}$ & $\begin{array}{c}845 \\
\text { (as for Dec. } \\
2012)\end{array}$ & 57,440 \\
\hline \multicolumn{2}{|c|}{} \\
\hline
\end{tabular}

${ }^{24}$ Cf. http://korean.go.kr (accessed 12-11-2017).

${ }^{25}$ As for August 2018, there were 174 KSIs in 57 countries - 100 of them in Asia, 41 in Europe, 3 in Africa, 4 in Oceania and 26 in America (cf. https://www.ksif.or.kr/ste/ksf/hkd/lochkd.do?menuNo=21101800, accessed 12-112018).

26 According to the MOE as for 2017, there were 1080 schools (cf. http://okeis.moe.go.kr/OKMS/pot/lfd/OkmsAcIndex7Mng.do?menu_no=13200, accessed 16-02-2018).

${ }^{27}$ According to the MOE currently there are 32 schools in 17 countries, the number of students is 13,770

(cf. http://www.moe.go.kr/boardCnts/view.do?boardID=348\&boardSeq=71492\&lev=0\&s earchType $=$ S\&status $Y N=W \&$ page $=1 \& s=$ moe $\& \mathrm{~m}=040103 \&$ op Type, accessed 16-022018). 


\begin{tabular}{|c|c|c|}
\hline $\begin{array}{c}\text { Korean Language Classes in Elementary } \\
\text { and Secondary Schools } \\
\text { (Kor. 초·중등 한국어 과목 수강) }\end{array}$ & 882 & 82,886 \\
\hline
\end{tabular}

Source: The NIKL『2014 숫자로 살펴보는 우리말』.

Although this article focuses mainly on institutions providing Korean language and culture classes outside of South Korea (and sponsored by the South Korean Government), it is also worthy to mention some of the very first institutions to provide the classes in South Korea, they are as follows:

1) 1959 - Yonsei University Korean Language Institute (Kor. 연세대학교 한국어어학당; the first Korean language institute in South Korea),

2) 1962 - the National Institute for International Education Development (NIIED, Kor. 국제교육진흥원; the course was for overseas Koreans),

3) 1964 - Myeongdowon (Kor. 명도원; established at the St. Franciscan Monastery for foreign missionaries, who came to the St. Franciscan convent),

4) 1969 - Seoul National University, Language Research Institute (Kor. 서울대학교 어학연구소),

5) 1977 - the National Institute for the Education of Korean Nationals Residing Abroad (Kor. 재외국민교육원),

6) 1986 - Korea University, the Institute for Korean Cultural Studies (Kor. 고려대학교 민족문화연구소),

7) 1988 - Ehwa Womans University, Ewha Language Center (Kor. 이화여자대학교 언어교육원),

8) 1989 - Sun Moon University, Korean Language Institute (Kor. 선문대학교 한국교육원),

9) 1990 - Sogang University, Korean Language Education Center (Kor. 서강대학교 한국어교육원),

10) 1993 - Kyung Hee University, Seoul Language Research Institute (Kor. 경희 대학교 서울 언어교육연구원 $)^{28}$

11) 1997 - Hanyang University, International Language Institute (Kor. 한양대학교 국제교육원) etc. ${ }^{29}$

${ }^{28}$ When Kyung Hee University (KHU) started KL course in 1993 it had only 2 students, however 10 years later the number exceeded 1000, in 2003 it doubled, in 2013 there were more than 6000 students - foreigners and overseas Korean, who completed KL course. Nowadays students from about 70 countries take classes on KL and culture at KHU (cf. 김중섭 2013: 39). 
According to the website 'Study in Korea' administered by the South Korean Government there are currently 192 Korean Language Institutes, usually operated within universities, that offer $\mathrm{KL}$ and culture courses. Apart from them, there are also institutions offering foreigners KL classes free of charge, in order to enable them quicker assimilation with the Korean society, among them are: Soul Global Center, Migrant Workers Welfare Society in Korea, Korea Support Center for Foreign Workers or Seoul Migrant Worker Center. ${ }^{30}$

\subsection{Brief Outline of books for Korean Language learners - historical perspective}

When not that many foreigners were studying Korean as a foreign language, books focused only on their level of proficiency appeared to be satisfactory. Nevertheless, with the globalization and the growing number of students, who for various reasons chose to study Korean, it was impossible to focus the book only on their level, which can be especially observed in books published in Korea and abroad in recent years. However, before analyzing the present book market offering various books for KL learners, let us say a few words on how the teaching methods and the teaching materials devoted to Korean have changed over time.

\footnotetext{
${ }^{29}$ It is also worthy to mention foreign universities, where KLE was firstly introduced: Tokyo University of Foreign Studies (1873); Saint Petersburg State University (1879); Columbia University (1934); University of Helsinki (1935); The Defense Language Institute US (1941); University of Hawaii (1946); SOAS University of London (1949); Charles University in Prague (1950); Peking University (1950); Harvard University (1952); Taiwan National University (1956) etc. (cf. 이지영 2002). In Poland, KL course was firstly introduced at Warsaw University (1953) and secondly at Adam Mickiewicz University (1988). With time both universities have introduced Korean Studies as their majors - UW in 1983, UAM in 2003. For details concerning the situation of Korean Studies in Poland refer to Borowiak (2017).

30 Cf. http://www.studyinkorea.go.kr/en/sub/college_info/room/language_search.do, (accessed 17-02-2018).
} 
Table 3. The changes in KLE with the focus on teaching methods and features of the textbooks

\begin{tabular}{|c|c|c|c|}
\hline Period & $\begin{array}{l}\text { The } \\
\text { teaching } \\
\text { method }\end{array}$ & $\begin{array}{l}\text { Books } \\
\text { (Teaching } \\
\text { Materials) }\end{array}$ & $\begin{array}{l}\text { Features of the Books } \\
\text { (Teaching Materials) }\end{array}$ \\
\hline Before 1870 & $\begin{array}{l}- \\
\text { focused on } \\
\text { translation } \\
\text { and } \\
\text { interpretation }\end{array}$ & $\begin{array}{l}\text { - vocabulary } \\
\text { books, }\end{array}$ & $\begin{array}{l}\text { - vocabulary books } \\
\text { for interpretation/ } \\
\text { translation, }\end{array}$ \\
\hline $\begin{array}{l}1870-1910 \\
\text { (the modern } \\
\text { quickening } \\
\text { period) }\end{array}$ & $\begin{array}{l}-\quad \text { imitation } \\
\text { of the mother } \\
\text { tongue's } \\
\text { acquisition } \\
\text { process, } \\
-\quad \text { audio- } \\
\text { lingual } \\
\text { approach } \\
\text { focused } \\
\text { on spoken } \\
\text { language, }\end{array}$ & $\begin{array}{l}\text { - grammar } \\
\text { books, } \\
\text {-conversation } \\
\text { books with } \\
\text { grammar notes, }\end{array}$ & $\begin{array}{l}\text { - grammar introduction } \\
\text { for the purpose } \\
\text { of missionary work, } \\
\text { - books are focused } \\
\text { on short dialogues, }\end{array}$ \\
\hline $\begin{array}{l}1910-1945 \\
\text { (the period of } \\
\text { quantitative } \\
\text { expansion) }\end{array}$ & $\begin{array}{l}-\quad \text { grammar } \\
\text { translation } \\
\text { method, }\end{array}$ & $\begin{array}{l}\text { - grammar } \\
\text { books, } \\
\text {-conversation } \\
\text { books, } \\
\text { - books for } \\
\text { overseas } \\
\text { Koreans, }\end{array}$ & $\begin{array}{l}\text { - systematization } \\
\text { of grammatical categories, } \\
\text { - dialogues in the form } \\
\text { of conversation, } \\
\text { - changes in orthography, } \\
\text { - trying to form a Unit, } \\
\text { - compilation of textbooks } \\
\text { for ethnic Koreans } \\
\text { residing in the post-Soviet } \\
\text { states, }\end{array}$ \\
\hline $\begin{array}{l}1946-1988 \\
\text { (development } \\
\text { towards } \\
\text { contemporary } \\
\text { teaching } \\
\text { materials) }\end{array}$ & $\begin{array}{l}\text { - audio- } \\
\text { lingual } \\
\text { approach } \\
\text { focused on } \\
\text { grammar, } \\
\text { spoken } \\
\text { language and } \\
\text { sentence } \\
\text { patterns, }\end{array}$ & $\begin{array}{l}\text { - grammar } \\
\text { books, } \\
\text {-conversation } \\
\text { books, } \\
-\quad \text { reading } \\
\text { books, } \\
- \\
\text { comprehensive } \\
\text { books, }\end{array}$ & $\begin{array}{l}\text { - lessons formed into } \\
\text { Units, } \\
\text { - since the 1960s the main } \\
\text { text is presented, } \\
\text { - Unit is focused } \\
\text { on the main text, and has } \\
\text { a systematic structure, } \\
\text { such as: text-vocabulary- } \\
\text { sentence pattern } \\
\text { explanation- sentence } \\
\text { and dialogue practice, } \\
\text { - books become focused } \\
\text { on the learner, }\end{array}$ \\
\hline
\end{tabular}




\begin{tabular}{|c|c|c|c|}
\hline $\begin{array}{l}1989-1999 \\
\text { (the develop- } \\
\text { ment } \\
\text { of contempor } \\
\text {-ary teaching } \\
\text { materials) }\end{array}$ & $\begin{array}{l}\text { - } \\
\text { communicate } \\
\text {-ve approach } \\
\text { focused } \\
\text { on spoken } \\
\text { language }\end{array}$ & $\begin{array}{l}\text { - } \\
\text { comprehensive } \\
\text { textbooks } \\
\text { for university } \\
\text { use, } \\
\text { - the beginning } \\
\text { of integrated } \\
\text { books } \\
\text { (practicing all } \\
\text { language skills) }\end{array}$ & $\begin{array}{l}\text { - comprehensive books } \\
\text { with dialogues, } \\
\text { vocabulary, grammar, } \\
\text { sentence patterns, } \\
\text { exercises, } \\
\text { listening, reading, } \\
\text { - separating 'Student's } \\
\text { Book' from } \\
\text { 'Workbook', } \\
\text { - making cultural } \\
\text { references in textbooks, } \\
\text { - levels 1-6/8 were } \\
\text { adjusted to the level } \\
\text { of learner's proficiency, }\end{array}$ \\
\hline $\begin{array}{l}\text { after } 2000 \\
\text { (the globali- } \\
\text { zation } \\
\text { of Korean } \\
\text { language } \\
\text { teaching } \\
\text { materials) }\end{array}$ & $\begin{array}{l}\text { - communica- } \\
\text { tive, } \\
\text { task-based, } \\
\text { culture } \\
\text { and literacy } \\
\text { centered } \\
\text { approach }\end{array}$ & $\begin{array}{lr}- & \text { integrated } \\
\text { books } & \\
- & \text { teacher's } \\
\text { book, } & \\
- & \text { textbooks } \\
\text { for } \quad \text { special } \\
\text { purposes, }\end{array}$ & 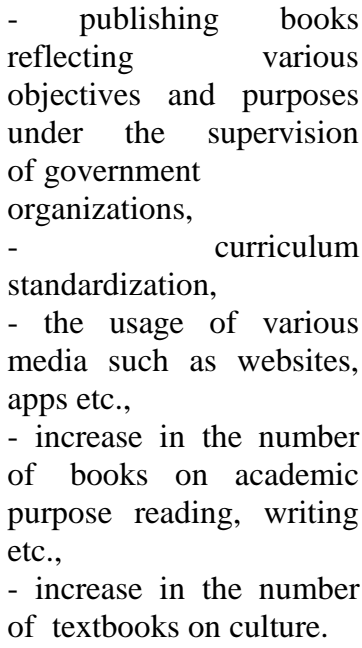 \\
\hline
\end{tabular}

Source: 고경민 (2012: 21-25).

Along with the constantly growing number of KL learners and in order to meet their changing needs, the compilation of new textbooks and other teaching materials became a necessity. According to the data gathered by the NIKL and published in 『국내외 한국어교재 백서』 (2009), from 1864 until January 2009 in 33 countries including Korea there were 3399 books published, as the Table 4. shows. 
Table 4. Korean language textbooks (teaching materials) published in South Korea and abroad

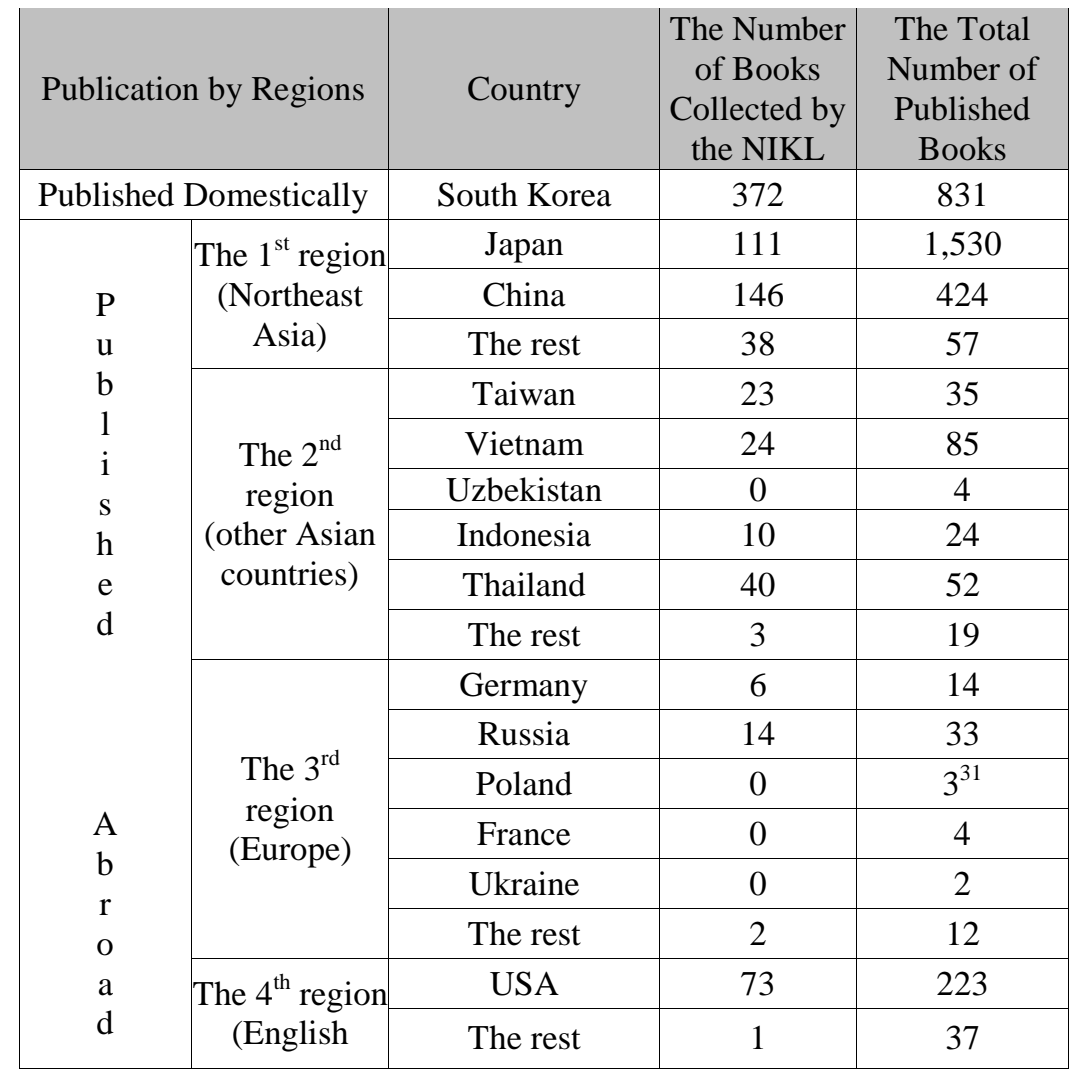

${ }^{31}$ According to the data presented in the Table 4., in Poland only 3 textbooks for KL learners were published until 2009. Nonetheless, as the below list shows, till then there were actually 4 books published (and after that few more). Among the former are: I. Textbooks: 1) Czhö Unhak et al. (1977) 'Teksty do nauki języka koreańskiego'. W- wa: Wyd UW; 2) Kim Dzonggyn et al. (1990) 'Teksty do nauki języka koreańskiego. Rozmówki koreańskie część II’. W-wa: Wyd. UW; 3) OgarekChoi H. et al. (1997) 'Język Koreański 1 -kurs podstawowy 『한국어 1』. W-wa: Dialog; 4) Ogarek-Choi H. et al. (2004) 'Język Koreański 2 - kurs dla zaawansowanych 『한국어 2』. W-wa: Dialog; II. Conversation books and dictionaries: 1) Jeong Deok Jeong (1998) 'Rozmówki koreańskie'『폴란드어 회화』, Wyd. Daewoo-FSO, 2) (1998) 'Słowniczek polsko-koreański, koreańskopolski' 『알기 쉬운 폴-한 한-폴 단어집』, Daewoo-FSO; 3) 김익성 (1999) 'Słowniczek polsko-koreański, koreańsko-polski' (1999)『알기 쉬운 폴-한 한-폴 단어장』, 명지출판사; 4) 정병권 ed. (2002) 'Słownik Polsko-Koreański' 『폴란드어-한국어 사전』 한국외국어대학교출판부. 


\begin{tabular}{|c|c|c|c|c|}
\hline & $\begin{array}{c}\text { speaking } \\
\text { countries) }\end{array}$ & - & 0 & 0 \\
\cline { 2 - 4 } $\begin{array}{c}\text { The } 5^{\text {th }} \text { region } \\
\text { (Latin } \\
\text { America) }\end{array}$ & Jordan & 2 & 2 \\
\cline { 2 - 4 } $\begin{array}{c}\text { The 6 } \\
\text { th region } \\
\text { (mainly Arab } \\
\text { and African } \\
\text { countries) }\end{array}$ & Turkey & 3 & 8 \\
\cline { 2 - 5 } & T3 countries & 868 volumes & 3,399 volumes \\
\hline
\end{tabular}

Source: NIKL (2009)『국내외 한국어 교재 백서』.

As a curiosity, we will present titles of some of the first studies devoted to KL by Europeans, who were in fact missionaries. They are as follows:

1) John Ross (1877) 'Corean primer', American Presbyterian Mission Press,

2) Félix-Clair Ridel (1881) 'Grammaire Coréenne’, 塔出版社,

3) John Ross (1882) 'Korean Speech with Grammar and Vocabulary', Shanghai: Kelly \& Walsh,

4) James Scott (1887) 'A Corean Manual or Phrase Book, with Introductory Grammar', Shanghai: Statistical Department of the Inspectorate General of Customs,

5) James Scott (1891) 'English-Corean Dictionary', Corea, Church of England Mission Press,

6) James Scott (1893) 'A Corean Manual or Phrase Book, with Introductory Grammar', $2^{\text {nd }}$ edition, Seoul: English Church Mission Press,

7) Horace G. A. Underwood (1890) 'The Concise Dictionary of the Korean Language in Two Parts', Yokohama,

8) James S. Gale (1897) 'Korean-English Dictionary', Yokohama,

9) James S. Gale (1903) 'Korean Grammatical Forms', Seoul Methodist Pub. House.

Among the first books prepared for foreign learners by Korean scholars are:

1) 박창해 (1960)『한국어 교본』, 연세대학교,

2) 명도원 (1964) 『선교사 한국어 교본』,

3) 박창해 (1965)『한국어 교본 II (An Intensive Course)』, 연세 대학교 출판부. 
Later on, books for English and Japanese speaking learners, as well as those for children of overseas Koreans, were published. Some of them are listed below:

4) 서울대학교 어학연구소(1970)『한국어 독본』, 서울대학교 출판부,

5) 임호빈 외(1987) 『외국인을 위한 한국어 문법』, 연세대학교 출판부, (the first grammar book for foreigners by Korean scholars)

6) Anthony V. Vandesande (1968) 『MYONGDO'S KOREAN'68』 분도출판사,

7) Samuel E. Martin (1969) ${ }^{\circledR B E G I N N I N G ~ K O R E A ~ ㅎ ㅏ ㄴ ㄱ ㅜ ㄱ ㅇ ㅓ ~ ㄷ ㅗ ㄱ ㅂ ㅗ ㄴ 』, ~}$ Yale University Press,

8) 서울대학교 어학연구소 (1980)『한국어 1』, 명지출판사,

9) 박기덕 (1980) ${ }^{『}$ KOREAN $2 』$, Yonsei University Press,

10) 고려대학교 민족문화연구소 (1986) 『한국어독본 I』, 우보사.

\section{The review of Korean language books and teaching materials published in South Korea after 1988}

After the Olympics in 1988 the new era in language teaching, manifesting itself in many dimensions has begun. The establishment of already-mentioned Korean Schools (Kor. 한국학교), Hangeul Schools (Kor. 한글학교) and others, has created a place to study for the children of overseas Koreans - the second or third generation descendants of Korean immigrants. EBS has started broadcasting 'Lectures on Basic Korean' (Kor. 기초 한국어 강좌), the Ministry of Culture and Sports (Kor. 문화체육부) ${ }^{32}$ in 1995 released 『한국어 교재』 (Korean Language Textbook) with CD-ROM, in 1998 the NIIED started running a website of Hangeul Schools and one year later Arirang TV started broadcasting programs on KL. All of this provided much easier access to KL, also the spoken one.

Nonetheless, with the inflow of foreigners marveled at Korean traditional culture the situation has started to change and so were books for them. Textbooks published between 1988-99 were comprehensive ones (dialogues, vocabulary, grammar, pattern sentences, exercises and reading) and were used by the publishing

\footnotetext{
${ }^{32}$ In 2008 the ministry changed its the name into the Ministry of Culture, Sports and Tourism (Kor. 문화체육관광부).
} 
universities or institutions during their classes, examples of which are listed below:
1) 이화여자대학교 언어교육원 (1991)『외국인을 위한 한국어』, 이화여자대학교출판부,
2) 한국어문화연수부 (1991)『한국어 회화』, 고려대학교민족문화 연구소,
3) 서울대학교 어학연구소 (1992)『한국어』, 대한민국문화부,
4) 이화여자대학교 언어교육원 (1998) 『말이 트이는 한국어』, 이화여자대학교출판부,
5) 연세대학교 한국어학당 (1992)『한국어』, 연세대학교출판부,
6) 연세대학교 한국어학당 (1999)『한국어 읽기』, 연세대학교 출판부.

In books published at the second part of that period the communicative approach was chosen, and as a result textbooks such as 『말이 트이는 한국어』 (1998) by Ewha Womans University, with speaking, listening, reading and writing were introduced and published, and for the first time workbook for students was compiled. Soon after other universities follow suit and the students' book was separated from the main textbook. The publishing of workbook for students was the beginning for preparation of books devoted to practicing individual skills such as reading, and books devoted only to reading will soon after be published - 연세대학교 한국어어학당 (1999)『한국어 읽기』 can serve as an example here.

Till about 2000 most of the learners were exchange students, studying at language institutes operated within universities. Nevertheless, after the 2002 Word Cup, people for various reasons started to learn Korean as a consequence, apart from the exchange students, South Korean society was also diversified by immigrants (economic and marriage based), children from the multicultural families, overseas Koreans, North Korean refugees, tourists etc. In May 2016, the Korea Times wrote that 'Foreign population in Korea reaches 1.9 million'. ${ }^{33}$ Accordingly, the institutions offering KL classes started to mushroom all around the world. Technological development along with the Internet expansion brought enormous possibilities, thanks to which the educational process became more diversified and pleasant. The number of TV programs devoted to KL

\footnotetext{
${ }^{33}$ Cf. http://www.kostat.go.kr/eng/ (accessed 21-01-2018).
} 
as those proposed by EBS rose. Portable game machines (Kor. 휴대용게임기) offering KL programs with the Hallyu star Bae Yongjoon (Kor. 배용준), online games designed for practicing Korean as well as cellphone apps have been developed.

Along with the active popularization and promotion of Korean culture and language, which resulted in the enormous increase in the KL learners, the need for developing textbooks and other teaching materials grew with every year.

In the era of globalization, Korean language textbooks reveal the following characteristics:

1) they correspond to the various reasons as to why learners want to study Korean, in other words they are learner-centered (apart from topic-oriented books, student practice books and various dictionaries have been published), they are to help foreigners to master Korean as well as possible, and possibly to get a job in Korea and reside there, ${ }^{34}$

2) a great number of them are devoted to particular language groups of learners (also books focused on practicing one or two skills at the same time appear),

3) bigger attention is also given to the content, which appears to be the necessity in the face of constant social and technological changes,

4) more attention is also paid to the graphic design of books, which is done not only in order to catch the learners' interest, but also to present the material in more accessible way (it seems to be of greater importance especially in the context of increasing competition in the publishing market),

5) technological development enabled compilation of books, dictionaries etc. using its power (CD, DVD, audiobooks, ebooks, e- learning courses, TV programs, websites, cellphone apps etc.); consequently, books and other teaching materials using TV and Internet websites as media have been introduced.

\footnotetext{
${ }^{34}$ This interpretation might appear rather absurd, yet looking at the rapidly ageing society and the conscious policy of Korean Government to attract foreigners, it might not be that absurd after all.
} 
What is more,

1) teaching became more standardized - levels of proficiency defined (although e.g. the same ending or grammatical construction can in fact be taught at the beginner level in one book and on intermediate one at another),

2) bigger attention is also given to teachers (as a result for their growing demand) - special majors at universities or training courses and workshops have been started,

3 ) in order to help the teachers to prepare their cases even better, books prepared especially for them also started to be published (some of them explain the usage of particular sentence patterns or endings, while others explain how to conduct the whole class; books used at KSIs, Hangeul Schools etc. can serve as examples of the latter).

Consequently, books and teaching materials used in the didactic process of Korean can be divided into few following classes. They will be characterized in a more detailed manner right after the below classification.

\section{Textbooks}

i) Regular textbooks (designed for a wider range of students),

ii) User (Learner)-oriented textbooks (designed for particular groups of users),

(1) for academics

a) subject-oriented textbooks (they are to help foreigners to prepare for studies at universities or for future job and focus on various fields such as literature, business etc.),

b) skill-oriented textbooks (writing, speaking, listening and speaking, reading etc.)

(2) for teachers (both Korean and non-Korean ones),

(3) for immigrants

a) marriage immigrants (for women only),

b) economic immigrants,

c) multicultural families,

d) for elementary, middle and high school children (of immigrants),

(4) for overseas Koreans (and their children), 

(5) for North Korean refugees,
(6) for tourists,

iii) Method-oriented books (they are focused on one particular method of teaching), e.g. teaching through:
(1) movies and dramas,
(2) songs,
(3) cooking,
(4) humor,
(5) idioms,
(6) stories (including e.g. Bible stories).

\section{Dictionaries}

i) different kinds of dictionaries as far as their form is concerned
(1) traditional (printed/ paper) dictionaries,
(2) electronic dictionaries,
(3) online dictionaries,
(4) app dictionaries (with or without the need for Internes access),

ii) different kinds of dictionaries as far as their language is concerned

(1) monolingual dictionaries: Korean-Korean dictionaries

(for more advanced learners)

a) lexical dictionaries (topic-oriented ones)

- idioms,

- antonyms,

- synonyms,

- onomatopoeias and mimesis,

- easily mistaken words,

b) grammar dictionaries (with conjugation forms)

- verbs,

- adjectives,

- verbs and adjectives,

- grammatical constructions (for learners and / or for teachers),

(2) bilingual dictionaries

a) form-oriented (for wider range of users),

- regular dictionaries,

- picture dictionaries, 
e.g. proverbs and idioms of Chinese origin, Korean

Body Language Dictionary,

b) User(Learner)-oriented

- for a wider range of learners

a) English-Korean, Korean-Russian, Polish-Korean etc.

b) collocation dictionary (Korean-English)

- for (foreign) teachers

- for specialists

- medical dictionary,

- business dictionary,

- dictionary of applied linguistics, etc.

\section{Internet resources}

(1) interactive textbooks offered by several universities, among them Yonsei University (https://www.coursera.org/learn/learnkorean), Sogang University (http://korean.sogang.ac.kr/) and KSIF

(http://www.sejonghakdang.org/sjcustu/opencourse/textbook/te xtbook/list.do) - for both teachers and students (though prior log in is required), the NIKL (http://www.korean.go.kr/front/page/pageView.do?page_id=P0 00152\&mn_id=38),

(2) e-books for learners and teachers (some of them for free download without prior registration) (http://www.kosnet.go.kr/cop/bbs/selectBoardArticle.do),

(3) interactive classes (online) Korean lessons with personal language tutors (through Skype), (http://www.verbalplanet.com/learn-korean.asp),

(4) online (video) lectures on Korean culture and language on sites such as KSIF (offered in several languages) and cyber universities e.g. CUK (http://korean.cuk.edu/en/), KHCU (http://lk.khcu.ac.kr/),

KOSNET (http://www.kosnet.go.kr/index.do?device=null) (though prior $\log$ in is required),

(5) online materials e.g. for TOPIK examination and other (http://www.topikguide.com/download-47th-topik-test-papers/, http://svk.mofa.go.kr/webmodule/htsboard/template/read/korbo ardread.jsp?typeID $=15 \&$ boardid $=2757 \&$ seqno $=1042985 \& \mathrm{c}=\& \mathrm{t}$ 
$=\&$ pagenum $=1 \&$ tableName $=$ TYPE_LEGATION $\& \mathrm{pc}=\& \mathrm{dc}=\&$

$\mathrm{wc}=\& \mathrm{lu}=\& \mathrm{vu}=\& \mathrm{iu}=\& \mathrm{du})^{35}$

\section{TV and Radio programs}

(1) Arirang and EBS,

(2) KBS World Radio (www.world.kbs.co.kr)

Apart from the above-mentioned materials in the context of KLE it is also worthy to mention the possibility to have private lessons over the phone with a native Korean and other activities performed by the NIKL - operating of the Korean Language Information Services with the usage of social media such as Facebook or Kakao Talk, managing call center etc. - all of that in order to provide the public services aiming at helping both Koreans and foreigners to use more refined language, meaning to promote the accurate usage of Korean. ${ }^{36}$

The above classification of KL didactic materials drew some light on their variety. Nonetheless, in order to provide some additional information about them, some of their examples will be presented below. As far as the textbooks are concerned, since they are extremely numerous, listing all of them would be difficult giving the extent of this article, that is why, as already mentioned, only some selected ones will be mentioned here. All titles in each category will be presented according to the year of publication and not the name of the author.

\footnotetext{
${ }^{35}$ There are also Korean universities and institutions, which provide didactic materials online, among them are: KOSNET (KL Study on the Internet, www.kosnet.go.kr), Overseas Koreans Foundation (www.study.korean.net), KSIF (www.sejonghakdang.org), Paichai University (www.eckfl.pcu.ac.kr), Sogang University (www.korean.sogang.kr), SNU Language Education Institute (www.lei.snu.ac.kr), Yonsei University (www.yskli.com), The Cyber University of Korea (www.korean.cuk.edu).

36 KL Call Center (tel. 1599-9979); Online help with KL usage (http://www.korean.go.kr) SNS Assistance: a) Kakao Talk: YellowD (https://yellowd.kakao.com), b) Facebook (http://www.facebook.com/urimal356).
} 


\section{BOOKS}

\section{i) Regular Textbooks}

The great majority of them are designed for students, some of them though are for kindergarten or primary school kids, who study KL as e.g. as the second language. They focus on explaining everyday vocabulary and commonly used grammar, are adjusted to the level of proficiency, often offered with a $\mathrm{CD}$, sometimes accompanied with a workbook. Some of them offer grammar and vocabulary explanation in one (as in the below (a), some in two or more foreign languages (as in (b)).

(a) 국립국어원 (2007) 『초급 한국어 (말하기, 듣기, 읽기, 쓰기)』 (Chinese, Vietnamese, Filipino language), 국립국어원 (2010) 『중급 한국어 (말하기, 듣기, 읽기, 쓰기)』 (English, Mongolian, Chinese, Vietnamese), 국립국어원 (2012) 『초급 한국어 말하기』(Russian, Spanish),

(b) 국립국어원 (2013) 『세종한국어 3/ 4』, 세종학당재단 (Korean, English, Chinese, Russian, French).

\section{ii) User(Learner)-oriented books}

(1) for academics (They are the most numerous.)

\section{a) Subject-Oriented Textbooks}

They are mainly focused on teaching specialized vocabulary from particular field(s) e.g. humanities, management, trade or art and are often offered with CDs. Despite containing some grammatical constructions, textbooks of this type have no exercises typical to regular textbooks. They are usually designed for learners, who wish to or are going to stay in Korea for longer period of time e.g. for university studies (not a language course), for work or residence in Korea since e.g. they got married to a Korean.

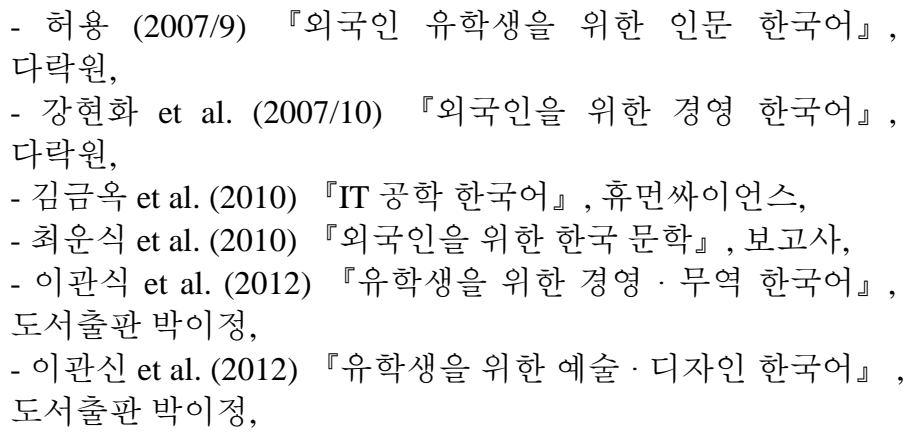


- 권오경 et al. (2012) 『외국인을 위한 한국 고전 작가론』, 박이정,

- 오선영 et al. (2014)『고급 한국어, 경제와 사회편』, 소통.

Some of the books do not have CD though. That is probably because they are focused on expanding the vocabulary from a particular field, and not on mastering the listening skills.

\section{b) Skill-Oriented Textbooks}

Among recently published books for KL learners, there is a considerable number of books, which are supposed to prepare foreigners to become even more qualified e.g. for writing reports, conducting a debate and such. They are focused on academics. Some are devoted to practicing one particular skill, while others focus on mastering two of them, as presented below.

\section{a. books focused on writing:}

- 장향실 et al. (2010/2011)『외국인 대학생을 위한 글쓰기의 기초』, 고려대학교출판부,

- 김호정 et al. (2011)『외국인 유학생을 위한 학술적 글쓰기』, 한국학중앙연구원출판부,

- 최윤곤 (2015)『한국어 리포트 작성입문』, 한국문화사,

- 이미란 et al. (2016)『외국인 유학생을 위한 대학 글쓰기』, 전남대학교 한국어문학연구소 총서 3. 경진출판,

- 이순정 et al. (2016) 『유학생을 위한 A+ 글쓰기』한글파크,

\section{b. books focused on speaking:}

- 김중섭 (2006)『외국인 학부 유학생을 위한 한국어 말하기』, 유씨엘,

- 서울대학교 언어교육원 (2009)『외국인을 위한 한국어 발음』, 랭기지플러스,

- 서울대학교 언어교육원 (2015)『외국인을 위한 한국어 발음』, 한글파크,

- 여미란 et al. (2015)『한국어 토론 입문』, 한국문화사,

\section{c. books focused on reading:}

- 조현용 (2006) 『외국인 학부 유학생을 위한 한국어 읽기』, 유씨엘,

- 김해옥 (2010)『외국인을 위한 한국문화 읽기』, 에피스테메 (방송대출판문화원), 
- 권영민 et al. (2011) 『외국인을 위한 한국문화 읽기』, 아름다운 한국어학교,

- 한국어읽기연구회 (2013)『한국의 가족 행사 - 외국인을 위한 한국어 읽기』, 학이시습,

- 양승국 et al. (2014)『외국인을 위한 한국문화 30 강』, 박이정,

\section{d. books focused on speaking and listening:}

- 이화여자대학교 언어교육원 (2008/2011) 『유학생을 위한 대학 한국어 $1 / 2$, 말하기·듣기, Express.

- 김경훤 et al. (2010) 『대학 한국어 1 , 듣기와 말하기』, 성균관 대학교 출판부,

\section{e. books focused on reading and writing:}

- 임종수 et al. (2003) 『가장 쉬운 한글 읽기 - 쓰기 (일본어판)』, 한글파크,

- 이화여자대학교 언어교육원 (2008)『유학생을 위한 대학 한국어 2 , 읽기·쓰기』, 이화여자대학교출판부,

- 김경훤 et al. (2010) 『대학 한국어 2, 읽기와 쓰기』, 성균관 대학교 출판부,

- 고려대학교 사고와 표현 교재편찬위원회 (2017) 『대학 한국어 $1 / 2$ - 비판적 읽기와 학문적 쓰기』, 고려대학교출판문화원,

- 이화여자대학교 언어교육원 (2018)『유학생을 위한 대학 한국어 $1 / 2$, 읽기·쓰기』, 이화여자대학교출판문화원 (개정판, 1 쇄 2008).

\section{(2) Books for teachers}

This type of books explains grammar issues or provides additional exercises to practice grammatical forms. They can be divided according to the nationality of the teacher - whether he or she is the native speaker of KL or a foreigner. Those for Korean teachers explain how to teach North Korean learners or primary, secondary and high school students - the offspring of immigrants, while those for foreign teachers are more focused on various types of activities, which can be used during classes.

\section{a) books for Korean teachers:}

- 임상수 et al. (2008) 『새터민 아동을 위한 교육 멘토링』, 교육 멘토링 총서 3 , 교육과학사,

- 신명선 et al. (2012)『새터민을 위한 한국어 어휘 교육』, 박이정,

- 국립국어원 (2015) 『초등학생을 위한 표준 한국어 1/2』, (교사용 지도서), 하우,

- 국립국어원 (2015) 『중학생을 위한 표준 한국어 1/2』, (교사용 지도서), 다락원, 
- 국립국어원 (2015)

『고등학생을 위한 표준 한국어 $1 / 2 』$, (교사용 지도서), 다락원,

\section{b) books for foreign teachers:}

- 허용 (2005) 『즐거운 한국어 수업을 위한 교실활동 $100 』$, 박이정,

- 구본관 et al. (2009) 『한국어 수업을 위한 문법활동집 - 초급』, 랭기지플러스,

- 송영숙 et al. (2013) 『한국어 교사를 위한 문형 예문집』, 국제한국어교육협회.

\section{(3) Textbooks for Immigrants}

Along with the growing number of foreign migrant workers and marriage immigrants, the idea of 'multicultural family' was introduced. In order to enable them better assimilation to Korean society some measures had to be taken. Consequently, books and educational courses for multicultural families were introduced and, books for their children - primary, middle and high school students, were also published. ${ }^{3738}$ A great number of those books were developed by the NIKL.

a) books for marriage migrants:

- 여성가족부 (2005)『여성이민자를 위한 한국어 교재』(초·중급), 장하진,

- 국립국어원 (2007) 『여성 결혼 이민자를 위한 한국어 첫걸음』, 문화관광부 및 국립국어원 ${ }^{39}$

- 국립국어원 (2010)『결혼이민자와 함께하는 한국어 $1 / 2 』(+\mathrm{CD})$, 한글파크,

- 국립국어원 (2011)『결혼이민자와 함께하는 한국어 3/ 4/6』 (+CD), 하우,

\footnotetext{
${ }^{37}$ It is also worthy to mention the existence of the National Center for Multicultural Education (Kor.

중앙다문화교육센터; http://www.nime.or.kr/search/total/41?searchOn=1\&targetOnly=archives, accessed 12-11-2018).

${ }^{38}$ When in 2006 prof. Lee Jeonghee at classes devoted to the research on KL textbooks (taught at KHU) asked as - graduate students to write one chapter of KL book for any target group we wished to, we were quite surprised that few students actually chose immigrant women married to Koreans, foreign workers and American soldiers. As it turned out, books devoted to these particular learner groups were soon published.

${ }^{39}$ Phrases are translated into 11 languages, which confirms the national variety of women to marry Koreans.
} 
- 국립국어원 (2012)『결혼이민자와 함께하는 한국어 5』 (+CD), 하우,

- 이정희 et al. (2015) 『이민자를 위한 한국어와 한국문화 기초』 $(+\mathrm{CD})$, 한국이민재다,

- 이정희 et al. (2015) 『이민자를 위한 한국어와 한국문화 초급 $1 / 2 』$ $(+\mathrm{CD})$, 한국이민재단,

- 이미혜 et al. (2015) 『이민자를 위한 한국어와 한국문화 중급 1/ $2 』(+\mathrm{CD})$, 한국이민재단,

\section{b) books for (foreign immigrant) workers:}

- 국제노동협력원 (2003) 『외국인 노동자를 위한 재미있는 한국어 $1 』$, 국제노동협력원,

- 국제노동협력원 (2007)『외국인 노동자를 위한 재미있는 한국어 $2 』$, 국제노동협력원,

- 농협 (2010)『외국인 근로자 고용 농업인 위한 생활회화집』, 농협.

- 허용 et al. (2012)『이주 노동자를 위한 아자아자 한국어 1』 (+CD), 한글파크,

- 허용 et al. (2012)『이주 노동자를 위한 아자아자 한국어

$2 』(+\mathrm{CD})$, 한글파크.

\section{c) books for multicultural families:}

- 한글파크 (2012)『다문화 가족을 위한 한국어 단어 카드 라라라 1 (공부)/ 2(놀이)/ 3(생활)/ 4(음식)』,

- 정월순 et al. (2015)『다문화 가족을 위한 문장으로 배우는 한국어』, 넥센미디어.

c) books for migrants' children:

- 양민정 et al. (2012)『엄마 · 아빠 나라 다문화 옛날이야기』, 한글파크,

- 국립국어원 (2013)『초등학생을 위한 표준 한국어 $1 / 2 』(+\mathrm{CD})$, 하우,

- 국립국어원 (2013) 『중학생을 위한 표준 한국어 $1 / 2 』(+C D)$, 다락원,

- 국립국어원 (2013) 『고등학생을 위한 표준 한국어 $1 / 2 』(+C D)$, 다락원,

- 국립국어원 (2016)『초등학생을 위한 표준 한국어 익힘책 $1 』(+\mathrm{CD})$, 하우. 


\section{(4) Textbooks for overseas Koreans}

Even though few books for overseas Korean (e.g. for children) have been published, regrettably they are not available in the biggest bookstore in Seoul - Kyobo Bookstore. There are however few books for children, devoted to English, Russian, French, Vietnamese, Thai etc. speaking learners and those for the wider use (written in Korean). The reason behind that could be the fact that they are available as ebooks - for both students and teachers, some of them are listed below. 40

- 재외동포교육진흥재단 (2006) 『한글학교 학생용 동화로 배우는 한국어』,

- 재외동포교육진흥재단 (2006) 『한글학교 학생용 한국 문화』,

- 재외동포교육진흥재단 (2006)『한글학교 학생용 한국 문학』,

- 한국교육과정평가원 (2010)『한국어 회화 1』,

- 한국교육과정평가원 (2012)『한국어 회화 2』,

-재외동포교육진흥재단 (2012)『한글학교 한국어 1 6』,

-재외동포교육진흥재단 (2012)『맞춤 한국어 1 6 영어권 (재외동포 어린이)』,

- 교육과학기술부, 국립국제교육원 (2012) 『한국인의 생활 I, $\mathrm{II} 』($ 일어권 $)$.

\section{(5) Books for North Koreans Refugees}

These books are to help North Koreans to understand South Korean reality and assimilate with the society, thus they include subjects such as community life, cultural life or private life.

- 권순희 et al. (2012)『북한이탈주민의 대한민국 정착을 위한 생활 어휘 1 (공공 생활)/2(문화 생활)/3 (개인 생활) 』, 하우,

- 권순희 et al. (2013) 『북한이탈주민의 대한민국 정착을 위한 생활 말하기』 $(+\mathrm{CD})$, 하우.

\section{(6) Books for tourists (also medical ones)}

Korea has become a very attractive tourist destination. It attracts not only regular tourists, who wish to experience Korean culture and to learn few phrases, but also those, who which to get a medical

${ }^{40}$ It is also worthy to mention the existence of the Educational Foundation for Koreans Abroad (EFKA, Kor. 재외동포교육진흥재단, http://www.efka.or.kr/user/main.asp), some nice e-learning sites developed especially for them (e.g. http://efka.co.kr/) and sites with dozens easily downloadable e-books (e.g. http://www.kosnet.go.kr/index.do?device=null). 
treatment there. South Korea is in fact becoming one of the major centers for medical tourism in Asia, this explains the importance of this type of tourists for the country and the rising demand for books developed especially for them. ${ }^{41}$

- 한민이 (2005)『바로 통하는 여행 한국어 (중국인용)』, 넥서스,

- 장미영 (2009)『병원 한국어 중국인을 위한 의료한국어』, 한국문화사,

- ブルーガイド編集部 (2010)『그림 손가락 회화 (한국어-일본어)』, 實業之日本社,

- 장미영 et al. (2012) 『병원 용어 (한국어-일본어) 의료 관광을 위한 필수 의료 용어 수록』, 어문학사,

- 김중섭 et al. (2012) ${ }^{『}$ Korean Phrase Book for Travelers (English- Korean, Korean-English)』, Hollym,

- 하이코 이탈 (2013)『독일인을 위한 한국어 여행 사전』, 문예리,

- 강선화 et al. (2013)『성신 한국어 초급 2: 음식 주문에서 여행까지 할 수 있어요』, 성신여자대학교출판부,

- 임금복 (2014)『성신 한국어 초급 3: 소개에서 여행과 명소까지』, 성신여자대학교출판부,

- 장미영 et al. (2014)『영어 환자를 위한 병원 한국어』, 역락,

- 장지연 et al. (2015)『여행, 유학, 비즈니스맨을 위한 자신만만 통 한국어』, 탑메이드북.

Although Korean language textbooks for soldiers of the US Armed Forces stationing in South Korea as well as diplomats have not been published yet, few universities offer classes especially for this kind of learners.

Since the importance of the TOPIK exam grew over time, various universities and educational centers started to follow the TOPIK scale in the textbooks while marking the levels of proficiency. Consequently, the following scale was or still is being used:

a) beginner 1-2 (초급 I, II), intermediate 1-2 (중급 I, II), advanced 1-2 (고급 I, II)

\footnotetext{
${ }^{41}$ The International Medical Travel Journal (INTJ) on the basis of data provided by the South Korean Ministry of Health and Welfare, points out that South Korea spends $\$ 1$ billion a year to attract medical tourists and that there are 1,709 registered hospitals/clinics along with 1,413 licensed private businesses that engage in marketing in order to attract this type of tourists (cf. https://www.imtj.com/country/KR/\#horizontalTab5, accessed 10-11-2018).
} 
(the scale was used from the $1^{\text {st }}$ edition of the exam in 1997 till the $34^{\text {th }}$ edition in Feb. 2014),

b) the six-number scale - 1 6 levels ( 1 급 $\sim$ 급)

(the scale is being used since the $35^{\text {th }}$ edition in June 2014 till present).

Apart from the above-mentioned subject- oriented textbooks or User(Learner)-oriented textbooks, there are also books, which use alternative ways of teaching through e.g. movies, songs, games, stories etc. Since they are designed for wider range of students and thus they bare some resemblance with the regular textbooks. They can in fact become their subcategory. Some of their titles divided according to the teaching method are listed below:

(1) Movies and dramas

- 편집부 (2006)『드라마 신입사원으로 배우는 한국어』 (일본어판), 아름다운한국어학교,

- 김숙자 et al. (2008)『오세암 - 영화로 배우는 한국어』, 한국학술정보,

- 편집부 (2011)『드라마로 배우는 생생 한국어 1』 (일본어판, 중국어판), 서강대학교 한국어교육원,

- 편집부 (2011)『드라마로 배우는 생생 한국어 2』 (중국어판), 서강대학교 한국어교육원,

(2) Songs

- 이선미 et al. (2012)『노래로 배우는 한국어』 (+CD), 하우,

- Park Sunyoung et al. (2016)『케이팝 코리안』, 다락원,

(3) Cooking

- 장미영 (2009)『요리로 배우는 한국어』, 한국문화사,

- 천선옥 (2010)『매콤 새콤 달콤 셰프 한국어』(+CD), 한글파크,

- 김영주 et al. (2011)『요리하며 배우는 한국어 - 요리한국어』, 한국문화사,

(4) Humor

- 최권진 (2009)『유머로 배우는 한국어 (중급)』, 한국문화사,

(5) Idioms

- 김충실 et al. (2006)『관용어로 배우는 한국어』, 박이정,

(6) Stories (and Bible stories)

- 김영주 et al. (2013)『성경이야기로 배우는 한국어 (아동용)』, 하우, 
- 김영주 et al. (2013)『성경이야기로 배우는 한국어 (청소년용)』, 하우,

- 김미숙 et al. (2015) 『이야기로 배우는 한국어 재미있는 이야기, 쉬운 한국어』, 박이정,

- 이은자 et al. (2015)『한국의 옛날이야기로 배우는 한국어, 한국문화』, 연락,

(7) Cartoons

- 이경은 et al. (2011)『4 컷 Cartoon 한국어 - 의성어-의태어』, 한글파크,

(8) Culture

- 순천향대학교 한국어교육원 (2008) 『문화로 배우는 한국어 2』, 보고사,

- 전미순 (2008)『문화 속 한국어 $1 』$, 랭기지플러스,

- 전미순 (2009)『문화 속 한국어 2』 (+CD), 랭기지플러스,

(9) News

- 장소원 et al. (2015) ${ }^{\circledR} \mathrm{YTN}$ 뉴스로 배우는 시사 한국어』 $(+\mathrm{CD})$, 박이정,

- Talk to Me in Korean (2015) ${ }^{『}$ News in Korean』, 롱테일북스.

\section{Dictionaries}

As far as the dictionaries are concerned, they can be divided into monolingual and bilingual ones. Both of them can furtherly be divided into two categories. The type of dictionary entry can become the criterium for dividing monolingual dictionaries into lexical and grammatical ones. Both of these types are developed for more advanced learners, since the explanation is given in Korean. Lexical dictionaries explain e.g. frequently misused words, idiomatic, onomatopoeic and mimetic expressions, while grammatical ones the conjugative forms of verbs and adjectives.

Bilingual dictionaries, on the other hand, can be divided according to the User - namely those for the majority of learners and those for the professionals. Both of them are not only prepared for KL students or foreign experts but also for Korean students studying foreign languages e.g. English and professionals as well. Examples of mono- and bilingual dictionaries are given below:

\section{i) Monolingual dictionaries: \\ a) Lexical dictionaries}

- 박영준 et al. (1996)『관용어 사전』, 태학사, 
- 임창호 (2001)『혼동되기 쉬운 말 비교 사전』, 우석,

- 이재운 et al. (2008)『뜻도 모르고 자주 쓰는 우리말 숙어 1000 가지』, 예담,

- 한국어교육연구소 (2015)『한국어 의성어·의태어』, 동양 Books,

\section{b) Grammatical dictionaries}

- 백봉자 (1999)『외국어로서의 한국어 문법 사전』, 연세대학교 출판부,

- 김정숙 et al. (2005) 『외국인을 위한 한국어 문법 2』, 커뮤니케이션북스,

- 남지순 (2007)『한국어 동사-형용사 활용 마법사』, 도서출판 박이정,

- 김종록 (2009)『외국인을 위한 표준 한국어 동사 활용 사전』, 박이정.

\section{ii) Bilingual dictionaries}

\section{a) Form-oriented dictionaries}

a. regular dictionaries (KL Dictionaries):

- 이기원 (2007)『한국어의 의성어와 의태어』, 한국문화사,

- 김하수 et al. (2007)『한국어 교육을 위한 한국어 연어 사전』, 커뮤니케이션북스,

- 오미정 et al. (2007)『외국인을 위한 한국어 외래어』, 월인,

- Park Brayan (2009)『한국어 형용사 500 활용 사전』, Hollym International Corp. SOTONG,

- 박규병 et al. (2013)『한국어 관용어 사전』, 도서출판 문예림.

\section{b. picture dictionaries:}

- Shapiro et al. (1998) 'The Oxford Picture Dictionary - English/Korean-', Oxford University Press,

- 강현화 (2009) 'Korean Picture Dictionary (English, Vietnamese, Indonesian, Mongolian)’ (+CD), 다락원,

- 강현화 (2013) 'Korean Picture Dictionary (Spanish, French, German)' $(+\mathrm{CD})$, 다락원,

- Carlson Jr. Richard et al. (2017) 'English-Korean Bilingual Children's Picture Dictionary Book of Colors', Createspace Independent Publishing Platform.

\section{b) User(Learner)-oriented dictionaries}

\section{a. for a wider range of learners}

- 넥서스사전편찬위원회 (2007)『(영한) 넥서스 영한 사전 』, 오분샤출판사, 
- 정병권 ed. (2002)『폴란드어 - 한국어 사전』, 한국어외국어 대학교출판부,

b. for (foreign) teachers (and students)

- 조현용 (2009)『한국인의 신체 언어』, 소통,

- 한국어교육연구소 (2015)『한국어 관용 표현』, 동양 Books,

- 한국어교육연구소 (2015)『한국어 속담 - 한자성어』, 동양 Books.

\section{c. for specialists (medical, business, applied linguistics,} interpretation and translation dictionaries)

- 이우주 ed. (2005)『컬러판 영한-한영 의학 사전』,
아카데미서적,
- 집필진 (2009)『한영-영한 비즈니스 인사이트 용어사전』,
비스니스맵,
- 박경자 et al. (2001)『(영한) 응용언어학 사전』, 도서출판
경진문화사,
-이진영 (2007)『통역·번역 기초 사전』, 이화여자대학교
출판부,
- 중앙대 국제대학원 통·번역 연구소 (2014)『국제회의
용어사전』, 문예림.

\section{Concluding Remarks}

For the last twenty years there has been a rise in demand for the KL due to cultural and commercial globalization as well as the Internet Revolution. The international interest in Korean culture such as dramas and music has increased tremendously, especially in Asia and Europe, leading to what has been known as the 'Korean Wave'. This state of affairs is also the result of conscious, well-planned initiatives and constant efforts taken up by the Korean Government, ministries, various institutions and agencies, focused on promotion and propagation of Korea's image, its values and identity all around the world. The expansion of Korean companies has also added its contribution here.

Consequently, there has also been an increase in the number of visitors from abroad as well as those, who reside in South Korea temporary or permanently (economic immigrants - both white and blue-collar workers, marriage immigrants, as well as students and medical tourists). Globalization realized the need to develop new 
teaching materials more adapted to the needs of constantly growing variety of learners. The Government has also been working on legislations, which would not only attract even more foreigners, but also on those, which would help foreigners to understand Korean and assimilate with the Korean society not only by providing KL courses but also lectures on the history, culture and tradition.

Technological development has not only diversified the means to which learners can learn and practice their language skills, but also owning to the access to various types of sources is simpler, fun, and even convenient. Nonetheless, despite all those various means to which students can learn the language by themselves to some extent, the demand for teachers is still growing. One of the aspects, which needs to be referred to here, is the attention KL teachers have received for the last few years. The teacher has started to be perceived as somebody who has to get proper education, and that is why from early 2000s at graduate schools and undergraduate courses the systematic KLE as a major was introduced. The number of institutions offering training for teachers is also on the rise. In 2014 there were 162 universities offering KL teaching majors and about 178 institutions which provided such training (of course for a shorter period of time). In fact, Koreans taking efforts in order to popularize and thus preserve Korean language and culture are demonstrating their patriotism.

In the era, where almost everybody speaks English, the constant and multifaceted promotion of KL for such a big and still growing scale, not only by providing books but also by establishing various institutions all around the world, where learners can study Korean, and where they can get to know Korean culture is a very positive phenomenon. We are positive that this trend will continue in the future.

Korean textbooks and teaching materials despite coming the long way - as far as the teaching methods, attractive form often reflecting the spirit of time (online books, e-books, apps etc.) and their variety are concerned, there is still a demand for User(Learner) oriented and topic-focused books, e.g. for corporate workers, managers, translators and interpreters, diplomats, airline staff and airport employees, since the number of foreigners, who work in Korean companies is growing with every year, and so is the number of Koreans traveling abroad. There is also the need for books for teenagers, since prospective learners interested in KL and culture are getting younger. Apart from already-mentioned books, dictionaries 
e.g. of synonyms and antonyms explaining in a more detailed manner the differences in usage of particular lexemes, as well as dictionary of neologisms would really be handy, if compiled.

\section{References}

Ahn, Jeong Hyeon (안정현). 2003. 『재외동포 교육용 한국어 교재 개발·공급 현황 및 개선 방안 연구』 (Jaeoedongpo gyoyugyong hangugeo gyojae gaebal·gonggeup hyeonhwang mit gaeseon bangan yeongu), 고려대학교 교육대학원 석사학위논문 (Koryeo daehakgyo gyoyukdaehagwon seoksahagwinonmun).

Ahn, Kyunghwa (안경화). 2005. 「한국어 교수 방법과 교수 방법론의 변천사」 (Hangugeo gyosu bangbeopgwa gyosu bangbeononui byeoncheonsa), 『한국어 교육론 I』 (Hangugeo gyoyungnon I), 한국문화사 (Hankook Munhwasa).

Baek, Bong-ja (백봉자). 2001. 「교재와 교수법을 통해 본 한국어 교육의 역사와 과제」 (Gyojaewa gyosubeobeul tonghae bon hangugeo gyoyugui yeoksawa gwaje), 『외국어로서의 한국어 교육』 (Oegugeoroseoui hangugeo gyoyuk), 연세대학교 한국어교사연수소 (Yonsei daehakgyo hangugeogyosayeonsuso), Vol. 26, pp. 11-31.

Bańczerowski, Jerzy. 2014. Lingwistyczne boje Ludwika Zabrockiego. Znaki Pamięci - Spuścizna Językoznawców Polskich Drugiej Połowy XX Wieku. Ed. Grochowski, Maciej \& Zaron, Zofia. Warszawa: PAN Komitet Językoznawstwa, pp.139-171.

Borowiak, Anna. 2017. 「폴란드의 한국어 교육현황 (Pollandeuui hangugeo gyoyukhyeonhwang). 『2017년 국외 한국어 전문가 초청 연수회』 (2017nyeon gugoe hangugeo jeonmunga chocheong yeonsuhoe), 6월 20일, 서울: 이화여자대학교 (6wol 20il, Seoul: Ewhayeoja daehakgyo).

Chinnammai, S. 2005. Effects of Globalization on Education and Culture. ICDE International Conference, Nov. 19-23, New Delhi, pp. 1-6. 
Cho, Hang Rok (조항록). 2003. 「한국어 교재 개발의 기본 원리와 실제 -연세대학교 한국어학당 교재 개발을 중심으로-」 (Hangugeo gyojae gaebarui gibon wolliwa silje - Yonsei daehakgyo hangugeohakdang gyojae gaebareul jungsimeuro-), 『외국어로서의 한국어교육』

(Oegugeoroseoui hangugeogyoyuk), 연세대학교 한국어교사연수소 (Yonsei hangugeogyosayeonsuso), Vol. 28, pp. 223-250.

daehakgyo

Cho, Hang Rok (조항록). 2005. 「외국어로서의 한국어 교육사」

(Oegugeoroseoui hangugeo gyoyuksa), 『한국어 교육론 $1 』 \quad$ (Hangugeo gyoyugnon 1), 한국문화사 (Hankook Munhwasa).

Cho, Hang Rok (조항록). 2013. 『한국어 교육 현황 점검 및 교육 지원 전략 연구』 (Hangugeo gyoyuk hyeonhwang jeomgeom mit gyoyuk jiwon jeollyak yeongu), 상명대학교 산학협력단 (Sangmyung daehakgyo sanhakhyeomnyeokdan). Gungnipgugeowon (국립국어원). 2009. 『국내외 한국어 교재 백서』 (Gungnaeoe hangugeo gyojae baekseo), 한국어세계화 재단 (Hangugeosegyehwa jaedan).

Gungnipgugeowon (국립국어원). 2014. 『2014 숫자로 살펴보는 우리말』 (2014 sutjaro salpyeoboneun urimal), 한국어세계화 재단 (Hangugeosegyehwa jaedan).

Gungnipgugeowon (국립국어원). 2014. 『국어연감』 (Gugeoyeongam), 한국어세계화 재단 (Hangugeosegyehwa jaedan).

Heo, Jae-Young (허재영). 2006. 『국어과 교과서와 교재 지도 연구』 (Gugeogwa gyogwaseowa gyojae jido yeongu), 한국문화사 (Hankook Munhwasa).

Heo, Jae-Young (허재영). 2007.『(제2언어로서의) 한국어 교육의 이해와 탐색』 (Je 2eoneoroseoui) hangugeo gyoyugui ihaewa tamsaek), 보고사 (Bogosa).

http://english.chosun.com/site/data/html_dir/2009/09/11/20090911008 59.html

http://english.visitkorea.or.kr/enu/CU/CU_EN_8_1_1.jsp http://www.ksif.or.kr/business/locSejong.do

Kim, Jung Sup (김중섭). 2011. 「한국어 교육의 변화와 한국어 교원의 미래」(Hangugeo gyoyugui byeonhwawa hangugeo gyowonui mirae), 『새국어생활』 (Saegugeosaenghwal), 국립국어원 (Gungnipgugeowon), Vol. 21-3, pp. 5-26. 
Kim, Jung Sup (김중섭). 2013. 「세종학당 성공을 위한 조건과 과제」 (Sejonghakdang seonggongeul wihan jogeongwa gwaje), 『한국어 문화연구』 (Hangugeo munhwayeongu), 한국어와문화연구 센터(Hangugeowamunhwayeongusenteo), Vol. 1-1, pp. 37-80.

Kim, Rok Hui (김록희). 2012. 『재외동포용 한국어 교재 분석 및 개선 방안, 『한글학교 한국어』와 『맞춤 한국어』를 대상으로-』 (Jaeoedongpoyong hangugeo gyojae bunseok mit gaeseon bangan, 『Hangeul hakgyo hangugeo $\_$wa ${ }^{『}$ Matchum hangugeo $₫$ reul daesangeuro-), 공주대학교 석사학위논문 (Kongju daehakgyo seoksahagwinonmun).

Kim, Young Ran (김영란). 2009. 『한국어 교육 교재의 변천 연구』 (Hangugeo gyoyuk gyojaeui byeoncheon yeongu), 고려대학교 대학원 박사학위논문 (Koryeo daehakgyo daehagwon baksahagwinonmun).

Ko, Kyoung-min (고경민). 2012. 『한국어 교재 변천사 연구』 (Hangugeo gyojae byeoncheonsa yeongu), 건국대학교 대학원 박사학위논문 (Konkuk daehakgyo daehagwon baksahagwinonmun).

Ko, Ye Jin (고예진). 2013. 『19세기 서양인의 한국어 교재 연구』 (19segi seoyanginui hangugeo gyojae yeongu), 부산대학교 대학원 박사학위논문 (Busandaehakgyo daehagwon baksahagwinonmun).

Lee, Jee Young (이지영). 2003. 「근현대 한국어 교재의 단원 구성 변천」 (Geunhyeondae hangugeo gyojaeui danwon guseong byeoncheon), 『국어교육연구』 (Gugeogyoyugyeongu), 서울대학교 국어교육연구소 (Seoul daehakgyo gugeogyoyugyeonguso), Vol. 11, pp. 369-410.

Lee, Jee Young (이지영). 2004. 「근현 대 민족어문교육 기초 연구 - 근현대 한국어 교재의 사적 고찰-」 (Geunhyeondae minjogeomungyoyuk gicho yeongu - geunhyeondae hangugeo gyojaeui sajeok gochal-), 『국어교육연구』 (Gugeogyoyugyeongu), 서울대학교 국어교육연구소 (Seoul daehakgyo gugeogyoyugyeonguso), Vol. 13, pp. 503-541.

Lee, Seong-young (이성영). 1992. 「국어과 교재의 특성」 (Gugeogwa gyojaeui teukseong), 『국어교육학연구』 (Gugeogyoyukagyeongu), 국어교육학회(Gugeogyoyukahoe). Vol. 2-1.

Min, Hyun Sik et al. (민현식 외), 2005. 「한국어 교육의 역사와 전망」 (Hangugeo gyoyugui yeoksawa jeonmang), 
『한국어교육론 $\quad 1 』 \quad$ (Hangugeogyoyungnon 1), 한국문화사 (Hankook Munhwasa).

Oh, Dae-hwan (오대환). 2009. 『식민지 시기 일본인을 위한 조선어 교육 연구 - '조선어 장려 정책'과 '경성 조선어연구회’를 중심으로-』 (Sigminji sigi ilbonineul wihan joseoneo gyoyuk yeongu - 'joseoneo jangnyeo jeongchaek'gwa 'gyeongseong daehakgyo daehagwon baksahagwinonmun).

Park, Gap Su (박갑수). 1999. 「한국어 교육의 과제와 전망」 (Hangugeo gyoyugui gwajewa jeonmang), 『국어교육연구 6』 (Gugeogyoyugyeongu 6), 서울대학교 국어교육연구소 (Seoul daehakgyo gugeogyoyugyeonguso), pp. 5-28.

Park, Young Soon (박영순). 2003. 「한국어 교재의 개발 현황과 발전 방향」 (Hangugeo gyojaeui gaebal hyeonhwanggwa baljeon banghyang), 『한국어교육』 (Hangugeogyoyuk), 국제한국어교육학회 (Gukjehangugeogyoyukhakhoe), Vol. 14-3, pp. 169-188.

Song, Hyang-Geun (송향근). 2011. 「한국어 교원 자격 제도의 현황과 과제」 (Hangugeo gyowon jagyeok jedoui hyeonhwanggwa gwaje), 『새국어생활』 (Saegugeosaenghwal), 국립국어원 (Gungnipgugeowon), Vol. 21-3.

Sun, Zhenyu (손진우). 2016. 『한류문화의 확산과 한국어 교육의 세계화 관계 연구』 (Hallyumunhwaui hwaksangwa hangugeo gyoyugui segyehwa gwangye yeongu), 상명대학교 대학원 석사학위논문 (Sangmeung daehakgyo daehagwon seoksahagwinonmun).

Zabrocki, Ludwik. 1963. Wspólnoty Komunikatywne $w$ Genezie i Rozwoju Języka Niemieckiego, cz. I, Warszawa: PWN.

Zabrocki, Ludwik. 1966. Językoznawcze Podstawy Metodyki Nauczania Języków Obcych, Warszawa: PWN. 